\title{
Role of Actin in Anchoring Postsynaptic Receptors in Cultured Hippocampal Neurons: Differential Attachment of NMDA versus AMPA Receptors
}

\author{
Daniel W. Allison, ${ }^{1}$ Vladimir I. Gelfand, ${ }^{1}$ Ilan Spector, ${ }^{2}$ and Ann Marie Craig ${ }^{1}$ \\ ${ }^{1}$ Department of Cell and Structural Biology, University of Illinois, Urbana, Illinois 61801, and ${ }^{2}$ Department of Physiology \\ and Biophysics, State University of New York, Stony Brook, New York 11794
}

We used actin-perturbing agents and detergent extraction of primary hippocampal cultures to test directly the role of the actin cytoskeleton in localizing GABA $_{A}$ receptors, AMPA- and NMDA-type glutamate receptors, and potential anchoring proteins at postsynaptic sites. Excitatory postsynaptic sites on dendritic spines contained a high concentration of F-actin that was resistant to cytochalasin $D$ but could be depolymerized using the novel compound latrunculin A. Depolymerization of F-actin led to a $40 \%$ decrease in both the number of synaptic NMDA receptor (NMDAR1) clusters and the number of AMPA receptor (GluR1)-labeled spines. The nonsynaptic NMDA receptors appeared to remain clustered and to coalesce in cell bodies. $\alpha$-Actinin-2, which binds both actin and NMDA receptors, dissociated from the receptor clusters, but PSD-95 remained associated with both the synaptic and nonsynaptic receptor clusters, consistent with a proposed cross-linking function. AMPA receptors behaved differently; on GABAergic

The mechanisms responsible for localizing neurotransmitter receptors to their sites of function at postsynaptic specializations, presumably via attachment to the cytoskeleton, are not well understood for the major synapse types in the mammalian brain. At the neuromuscular junction, acetylcholine receptors are anchored to the actin cytoskeleton by association with rapsyn/43K and additional linker proteins (for review, see Carbonetto and Lindenbaum, 1995; Sanes, 1997). On spinal cord neurons, there is evidence that inhibitory glycine receptors are anchored by attachment to gephyrin (Kirsch and Betz, 1993), which binds tubulin and is highly dependent on microtubules and partially dependent on actin microfilaments for its localization (Kirsch et al., 1991; Kirsch and Betz, 1995). The specific concentrations of $\mathrm{GABA}_{\mathrm{A}}$ receptors in inhibitory postsynaptic membranes (Somogyi et al., 1989; Craig et al., 1994) and of members of all glutamate receptor classes (AMPA/kainate, NMDA, and metabotropic) in excitatory postsynaptic membranes (Petralia and Wenthold, 1992; Baude et al., 1993; Craig et al., 1993; Aoki et al., 1994; Nomura et al., 1994; Petralia et al., 1994; Rao and Craig, 1997) indicate that

\footnotetext{
Received Sept. 25, 1997; revised Jan. 16, 1998; accepted Jan. 21, 1998.

This work was supported by the Markey Charitable Trust, by National Institutes of Health Grants NS33184 to A.M.C. and GM52111-01 to V.I.G., and by National Science Foundation Grant MCB 95-31231 to V.I.G. We thank Anna S. Serpinskaya for excellent technical assistance and J. Campanelli, A. Rao, and S. Rogers for comments on this manuscript.

Correspondence should be addressed to Dr. Ann Marie Craig, Department of Cell and Structural Biology, University of Illinois, B107 CLSL, 601 South Goodwin Avenue, Urbana, IL 61801.

Copyright (ㄷ) 1998 Society for Neuroscience $\quad 0270-6474 / 98 / 182423-14 \$ 05.00 / 0$
}

neurons, the clusters redistributed to nonsynaptic sites, whereas on pyramidal neurons, many of the clusters appeared to disperse. Furthermore, in control neurons, AMPA receptors were detergent extractable from pyramidal cell spines, whereas AMPA receptors on GABAergic neurons and NMDA receptors were unextractable. $\mathrm{GABA}_{\mathrm{A}}$ receptors were not dependent on F-actin for the maintenance or synaptic localization of clusters. These results indicate fundamental differences in the mechanisms of receptor anchoring at postsynaptic sites, both regarding the anchoring of a single receptor (the AMPA receptor) in pyramidal cells versus GABAergic interneurons and regarding the anchoring of different receptors (AMPA vs NMDA receptors) at a single class of postsynaptic sites on pyramidal cell dendritic spines.

Key words: actin; postsynaptic density; AMPA receptor; NMDA receptor; GABA receptor; dendritic spine; $P S D-95$

these receptors must be anchored in some manner by cytoskeletal elements, although there is little direct evidence. The functional state of the NMDA subtype of glutamate receptor is also mechanosensitive and regulated in a calcium-dependent manner by the actin cytoskeleton (Rosenmund and Westbrook, 1993; Paoletti and Ascher, 1994).

Many transmembrane proteins are anchored to actin via a direct linkage through bridging proteins, whereas other membrane proteins are thought to be trapped loosely within membrane domains formed by spectrin-based corrals (for review, see Bennett and Gilligan, 1993; Beck and Nelson, 1996). The scaffold for attachment of synaptic receptors likely resides in the postsynaptic density (PSD), an electron-dense and detergent-resistant core region of the postsynaptic specialization just beneath the membrane (Peters et al., 1991; Kennedy, 1997). Excitatory (asymmetric) synapses contain pronounced PSDs and most often occur on dendritic spines, structures that lack neurofilaments and microtubules but are dominated by high concentrations of actin filaments oriented longitudinally in the neck and forming a lattice in the head (Fifkova and Delay, 1982; Matus et al., 1982; Cohen et al., 1985; Harris and Kater, 1994). Thus it is very likely that actin filaments are intimately involved in controlling spine shape and may mediate cytoskeletal attachment of glutamate receptors and interacting postsynaptic proteins.

Recently several potential glutamate receptor anchoring proteins have been identified including $\alpha$-actinin-2, calmodulin, and PDZ domain proteins specific for NMDA receptors (PSD-95/ SAP90, chapsyn/PSD-93, and SAP102), AMPA receptors 
(GRIP), and class I metabotropic receptors (Homer) (Kornau et al., 1995; Ehlers et al., 1996; Kim et al., 1996; Muller et al., 1996; Brakeman et al., 1997; Dong et al., 1997; Wyszynski et al., 1997). Of these proteins found to interact with glutamate receptors, the only one known to interact with conventional cytoskeletal elements is $\alpha$-actinin-2, an actin cross-linking protein. However, because most of these receptor-interacting proteins consist of numerous interaction domains, they may form such a highly cross-linked network that they do not require association with conventional cytoskeletal elements for their localization or stabilization of bound receptors.

Here we used actin-perturbing agents and detergent extraction of primary hippocampal cultures to test directly the roles of actin filaments in localizing $\mathrm{GABA}_{\mathrm{A}}$ receptors, AMPA- and NMDAtype glutamate receptors, and the NMDA receptor-interacting proteins PSD-95 and $\alpha$-actinin- 2 at postsynaptic sites.

\section{MATERIALS AND METHODS}

Cell cultures. Rat hippocampal cultures were prepared using previously described methods (Banker and Cowan, 1977; Goslin and Banker, 1991). Briefly, hippocampi were dissected from $18 \mathrm{~d}$ rat embryos and dissociated using trypsin and trituration through a Pasteur pipette. The neurons were plated on coverslips coated with poly-L-lysine in minimal essential medium (MEM) with $10 \%$ horse serum at an approximate density of 2400 cells $/ \mathrm{cm}^{2}$. After the neurons had attached to the substrate, they were transferred to a dish containing a glial monolayer and maintained for up to 3 weeks in serum-free MEM with N2 supplements. For studies of the NMDA receptor, the cultures were treated chronically from 14-21 d in culture with $100 \mu \mathrm{M}$ 2-amino-5-phosphonovalerate (APV) as described previously (Rao and Craig, 1997). Cytochalasin D or latrunculin A were added directly to the culture medium from concentrated DMSO stocks. Reversal of the effects of latrunculin A was accomplished after a $24 \mathrm{hr}$ treatment in latrunculin A by a $24 \mathrm{hr}$ reversal in a fresh glial dish with conditioned MEM plus N2 supplements lacking latrunculin A. Cytochalasin D was obtained from Sigma (St. Louis, MO). Latrunculin A was isolated from the Red Sea sponge Negombata (known previously as Latrunculia magnifica) as described previously (Groweiss et al., 1983). In brief, samples of the sponge were lyophilized and extracted for $8 \mathrm{hr}$ in hexane, followed by extraction in chloroform. The resulting liquid phase was collected and chromatographed twice on Sephadex columns followed by a Silica $\mathrm{H}$ column to yield the pure compound. The structure of the pure compound was confirmed by nuclear magnetic resonance spectroscopy. Latrunculin A is now also available from Molecular Probes (Eugene, OR).

Immunocytochemistry. For immunocytochemistry not involving NMDA receptors, neurons were fixed at $20-23 \mathrm{~d}$ in culture in warm $4 \%$ paraformaldehyde and $4 \%$ sucrose in PBS for $15 \mathrm{~min}$ and were permeabilized with $0.25 \%$ Triton X-100 for $5 \mathrm{~min}$. The cultures were incubated with $10 \%$ bovine serum albumin (BSA) for $30 \mathrm{~min}$ at $37^{\circ} \mathrm{C}$ to block nonspecific staining and were incubated with the primary antibodies in $3 \%$ BSA. For stainings involving the NMDAR1 antibody, the 3-week neurons were simultaneously fixed and permeabilized in methanol for 15 min at $-20^{\circ} \mathrm{C}$, followed by the $10 \%$ BSA block and primary antibody staining. Primary antibodies used included guinea pig anti-GluR1 antiserum (gift of R. L. Huganir, Johns Hopkins University; 1:1600), rabbit anti-GluR1 affinity-purified antibody (Upstate Biotechnology, Lake Placid, NY; 1:1000), and monoclonal antibody 54.1 to NMDAR1 (PharMingen, San Diego, CA; 1:100-1:5000 depending on the lot) for the glutamate receptors. Presynaptic sites were labeled with either a rabbit antiserum G95 against synaptophysin (gift of P. DeCamilli, Yale University; 1:8000) or a monoclonal antibody against the synaptic vesicle protein SV2 (gift of K. M. Buckley, Harvard University; 1:50). Microtubule-associated proteins were stained with a rabbit antiserum against MAP2 (\#266; gift of S. Halpain, Scripps Institute; 1:20,000) and a monoclonal antibody against dephospho-tau-1 (Boehringer Mannheim, Indianapolis, IN; 1:400). F-actin was labeled with rhodamine phalloidin (Molecular Probes; 1:10,000). $\alpha$-Actinin was stained with monoclonal antibody EA-53 (Sigma; 1:20,000), and PSD-95 was stained with a guinea pig antiserum (gift of M. Sheng, Harvard University; 1:300). Neurons were incubated in primary antibodies for $2 \mathrm{hr}$ at $37^{\circ} \mathrm{C}$ and in appropriate secondary antibodies for $45 \mathrm{~min}$ at $37^{\circ} \mathrm{C}$. Secondary antibodies were conjugated to fluorescein, Texas Red, or 7-amino-4-methylcoumarin3 -acetic acid (Vector Laboratories, Burlingame, CA; 1:200-1:600). The coverslips were mounted in elvanol with $2 \% 1,4-$ diazabicyclo[2,2,2]octane. Fluorescent images of the neurons were obtained using a Zeiss Axioskop microscope with a $63 \times, 1.4$ numerical aperture lens and a Photometrics series 250 cooled CCD camera. Images were prepared for presentation using OncorImage and Adobe Photoshop software.

Quantitation. To quantitate the data from the immunocytochemistry, neurons were chosen randomly for image acquisition (for GluR1/synaptophysin/phalloidin, 20 cells each from five separate experiments for paired control and latrunculin A treatments; for NR1/synaptophysin, 10 cells each from five separate experiments for paired control and latrunculin A treatments). All image analysis was performed such that the experimenter was blind to the treatment group. For each neuron, two dendrites were chosen for analysis from the phase contrast image, and their length was measured. To count GluR1 or NR1 clusters per dendrite length, we processed the digital images using Oncor imaging software. Before we measured fluorescence intensities, images were background subtracted by a dark field image and divided by the image of a uniform fluorescence field to normalize for potential nonuniformity in illumination. Images were subjected to a user-defined intensity threshold to select spines or clusters (with intensity approximately twofold or greater above the parent dendrite), a selection for the region of interest, and a count of the number of clusters or spines along each chosen dendrite. For NR1, all clusters on spines and shafts were counted (see Fig. 8), whereas for GluR1, the diffuse labeling of dendritic shafts was high, and we could only reliably observe GluR1 clusters on spines (see Fig. 5). Hence we report "GluR1-labeled spines" that are equivalent to spiny GluR1 clusters. The data were compiled in Microsoft Excel, analyzed in Statview, and plotted using CricketGraph.

Western blot analysis. Hippocampal cultures were grown at a density of $14,300 \mathrm{cells} / \mathrm{cm}^{2}$ and used at $18-19 \mathrm{~d}$ in culture for Western blot analysis. For extraction, the neurons were treated with $1 \%$ Triton X-100 and $4 \%$ polyethylene glycol (PEG; molecular weight, 40,000) in BRB80 buffer $(80$ mM PIPES, $1 \mathrm{~mm} \mathrm{MgCl}_{2}$, and $1 \mathrm{~mm}$ EGTA) for $5 \mathrm{~min}$, rinsed in BRB80, and scraped into sample buffer for Western blots; a few coverslips were also fixed for staining. Nonextracted cultures were scraped into warm PBS, collected by centrifugation, and resuspended in Laemmli buffer. The samples were analyzed by SDS-PAGE and blotted onto nitrocellulose. Blots were probed with antibodies against GluR1 (Upstate Biotechnology; 1:5000) and NMDAR1 (PharMingen; 1:1000). HRP-conjugated secondary antibodies (Jackson ImmunoResearch, West Grove, PA; $1: 10,000)$ were used in combination with chemiluminescent Super-Signal HRP substrate (Pierce, Rockford, IL) to produce the signals on x-ray film before digital scanning. Blots were then stripped with SDS and $\beta$-mercaptoethanol, reprobed with monoclonal antibody $\mathrm{C} 4$ against actin (Boehringer Mannheim; 1:1000) and a polyclonal antibody against $\alpha$-actinin-2 (4B2; gift of M. Sheng and A. H. Beggs, Harvard University; 1:2000), and visualized as described above.

\section{RESULTS}

\section{Actin filaments and AMPA receptors are concentrated in dendritic spines}

Primary cultures from embryonic rat hippocampus develop excitatory synapses on dendritic spines with morphologies similar to those seen in vivo, although sometimes with a less pronounced PSD (Bartlett and Banker, 1984; Papa et al., 1995). Postsynaptic clusters of both AMPA- and NMDA-type glutamate receptors develop on the neurons and are generally numerous by 3 weeks in appropriate cultures (Craig et al., 1993; Rao and Craig, 1997). The pyramidal neurons form both spiny and shaft glutamatergic postsynaptic sites, whereas the GABAergic neurons, which comprise $\sim 7 \%$ of the cultured neurons, develop primarily shaft synapses (Craig et al., 1993; Benson et al., 1994).

We show here that excitatory synapses on dendritic spines in culture exhibit high concentrations of F-actin (Fig. 1C), as do dendritic spines in vivo (Matus et al., 1982). Embryonic rat hippocampal neurons in low density culture were triple-labeled with rhodamine phalloidin for F-actin and with antibodies for the AMPA-type glutamate receptor subunit GluR1 and for synapto- 

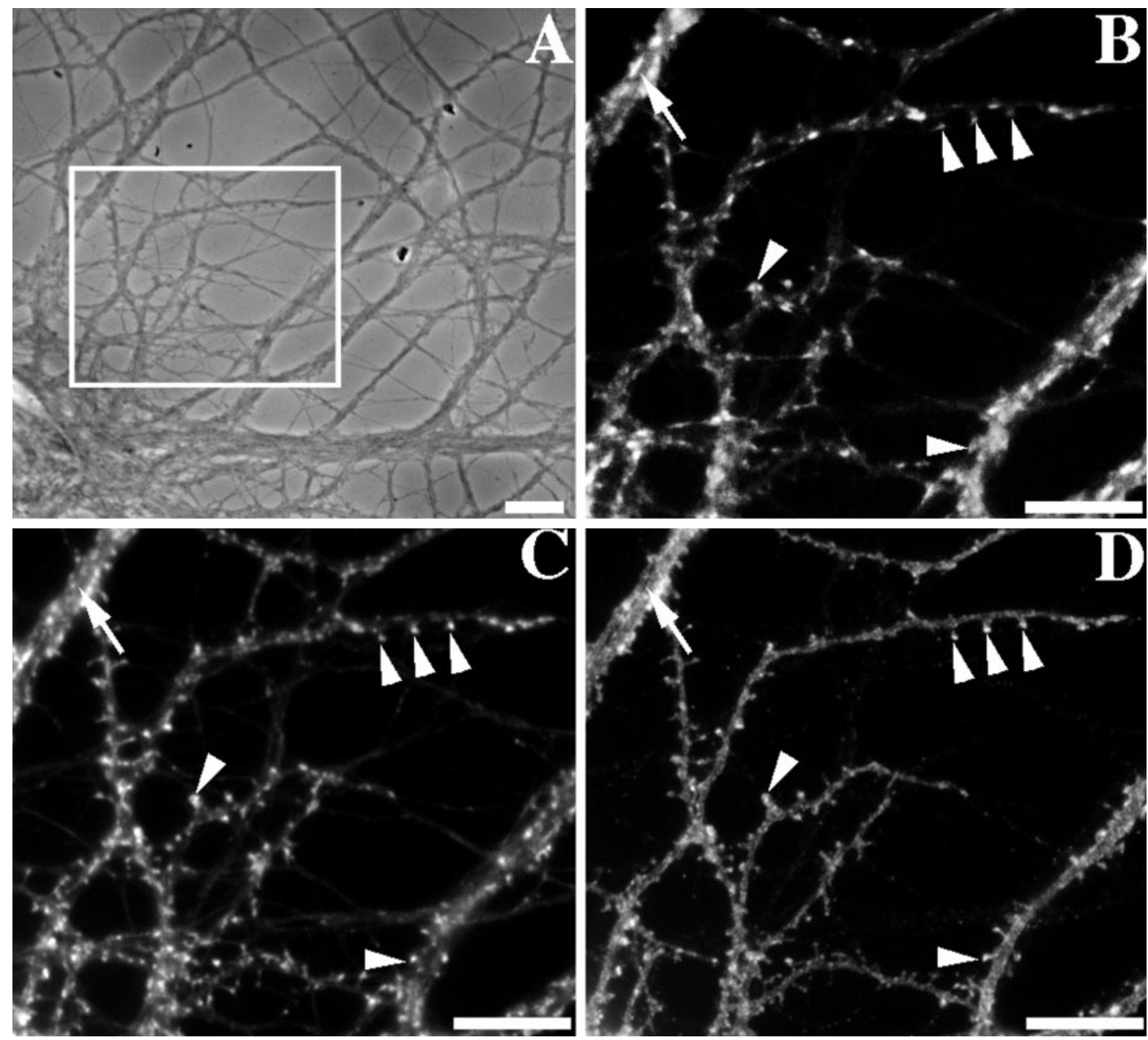

Figure 1. Coclustering of GluR1 and F-actin at synapses on dendritic spines of cultured rat hippocampal neurons. $A$, Phase contrast image of a typical pyramidal neuron at 3 weeks in culture (boxed area shows region enlarged in $B-D$ ). $B-D$, Staining with an antibody against the synaptic vesicle protein SV2 to label presynaptic terminals $(B)$, with rhodamine phalloidin to label F-actin $(C)$, and with an antibody against the GluR1 subunit of the AMPA-type glutamate receptor $(D)$. GluR1 and F-actin were present at high concentrations at some spiny synapses (arrowheads). In contrast, synapses on dendrite shafts of pyramidal neurons did not exhibit high concentrations of F-actin or of GluR1 (arrow); these may correspond to glutamatergic synapses lacking concentration of the AMPA receptor or to GABAergic synapses. Scale bars, $10 \mu \mathrm{m}$.

physin as a marker for presynaptic terminals (Fletcher et al., 1991). In mature neurons ( $\geq 3$ weeks in culture), these three proteins appeared concentrated together at synaptic sites on dendritic spines (Fig. 1). F-actin was also present in a filamentous pattern throughout the rest of the neuron, but the highest concentrations were observed at dendritic spines. Essentially all dendritic spines that stained positive for GluR1 were enriched for F-actin. F-actin was detectable at low levels but not concentrated at dendrite shaft synapses, including shaft synapses containing clusters of either GluR1 or GABA receptors (data not shown).

\section{Actin filaments within spines are particularly stable but can be disrupted with latrunculin $A$}

We set out to disrupt actin filaments at postsynaptic sites to determine the effects on clustering and/or synaptic localization of neurotransmitter receptors and of potential anchoring proteins. Disruption of F-actin is typically achieved in most cell types using cytochalasin D or related compounds. Cytochalasin D has many effects on actin; one activity is to cap the fast-growing plus end of the actin filament, preventing further polymerization. Because of other processes that sever actin filaments, this generally leads to a loss of filaments of normal length and an abundance of very short actin filaments (Cooper, 1987). To test its effectiveness on hippocampal cultures, we incubated neurons after 3 weeks in culture in several concentrations of cytochalasin D ranging up to $10 \mu \mathrm{g} / \mathrm{ml}$. After up to $24 \mathrm{hr}$ of treatment, the cultures were fixed and stained with rhodamine phalloidin (Fig. 2E,G). The F-actin within the somata and neurite shafts was effectively reduced by cytochalasin D, but F-actin was still concentrated within the spines, similar to the control neurons. This result indicates that the filamentous actin within dendritic spines is selectively resistant to destruction by cytochalasin D.

Because we were unable to depolymerize F-actin in spines using cytochalasin $\mathrm{D}$, we tried another actin-specific drug with a different mechanism of action. Latrunculin A, a compound iso- 

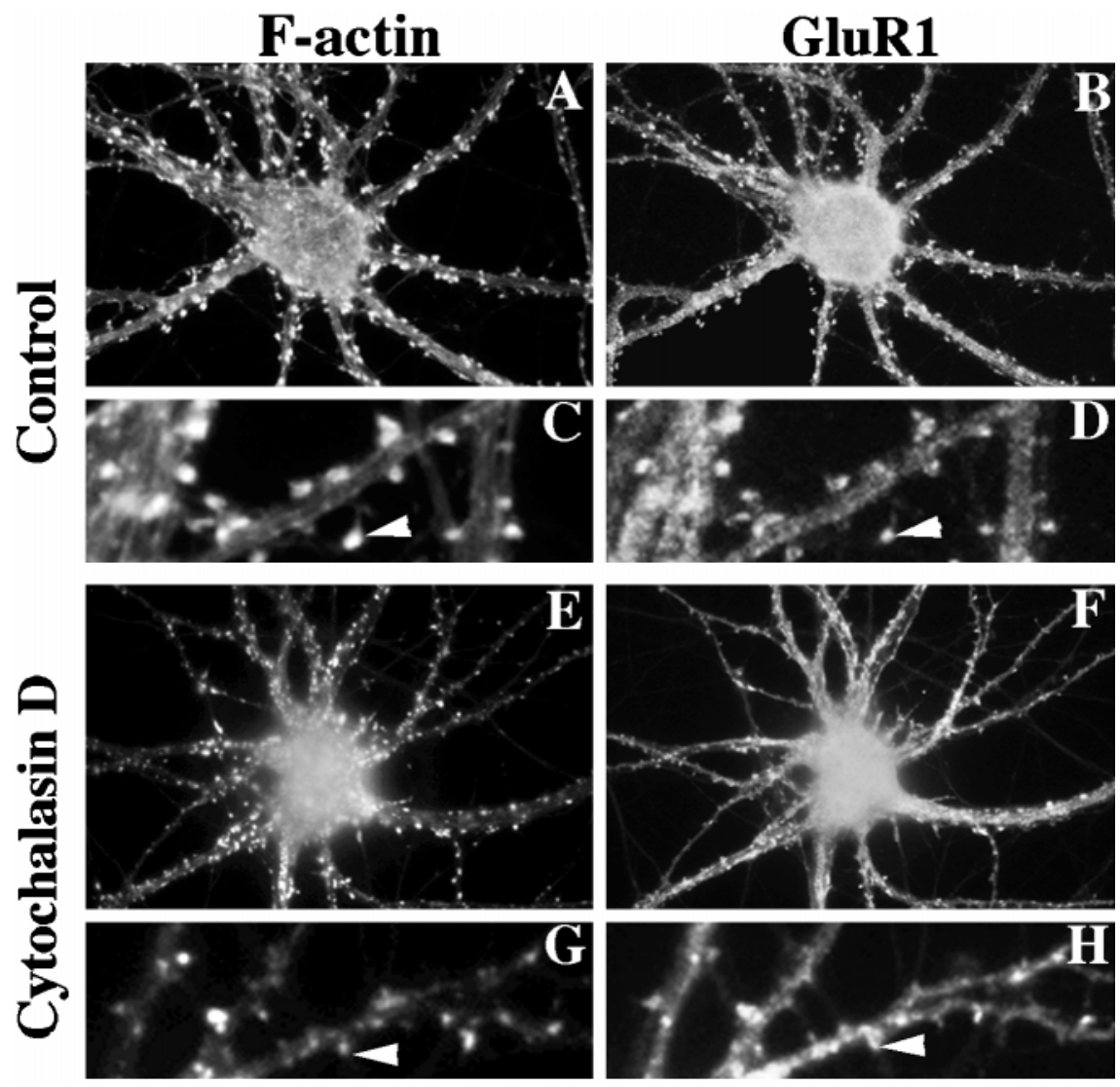

Figure 2. Disruption of neuronal F-actin and its effect on GluR1-labeled spines. Neurons were stained at 3 weeks in culture with rhodamine phalloidin to label F-actin $(A, C, E, G, I, K, M, O)$ and with an antibody against GluR1 $(B, D, F, H, J, L, N, P)$. The smaller boxes $(C, D, G, H, K, L, O, P)$ show enlarged regions from the neurons above (arrowheads represent spines). There were many spines with concentrations of both F-actin and GluR1 in control neurons $(A-D)$ and after treatment with $10 \mu \mathrm{g} / \mathrm{ml}$ cytochala$\sin \mathrm{D}$ for $24 \mathrm{hr}(E-H)$. Although much of the cortical actin was disrupted by cytochalasin $\mathrm{D}$, the spines were still positive for both F-actin $(E, G)$ and GluR1 $(F$, $H)$. In contrast, after a $24 \mathrm{hr}$ treatment with $5 \mu \mathrm{M}$ latrunculin A, most of the F-actin was depolymerized $(I, K)$ with a corresponding loss of GluR1-labeled spines $(J, L)$. Some neurons exhibited apparently "deflated" spines after latrunculin A treatment, protrusions close to the shafts lacking F-actin $(M, O)$ but still containing concentrations of GluR1 $(N, P)$. Scale bars, $10 \mu \mathrm{m}$.
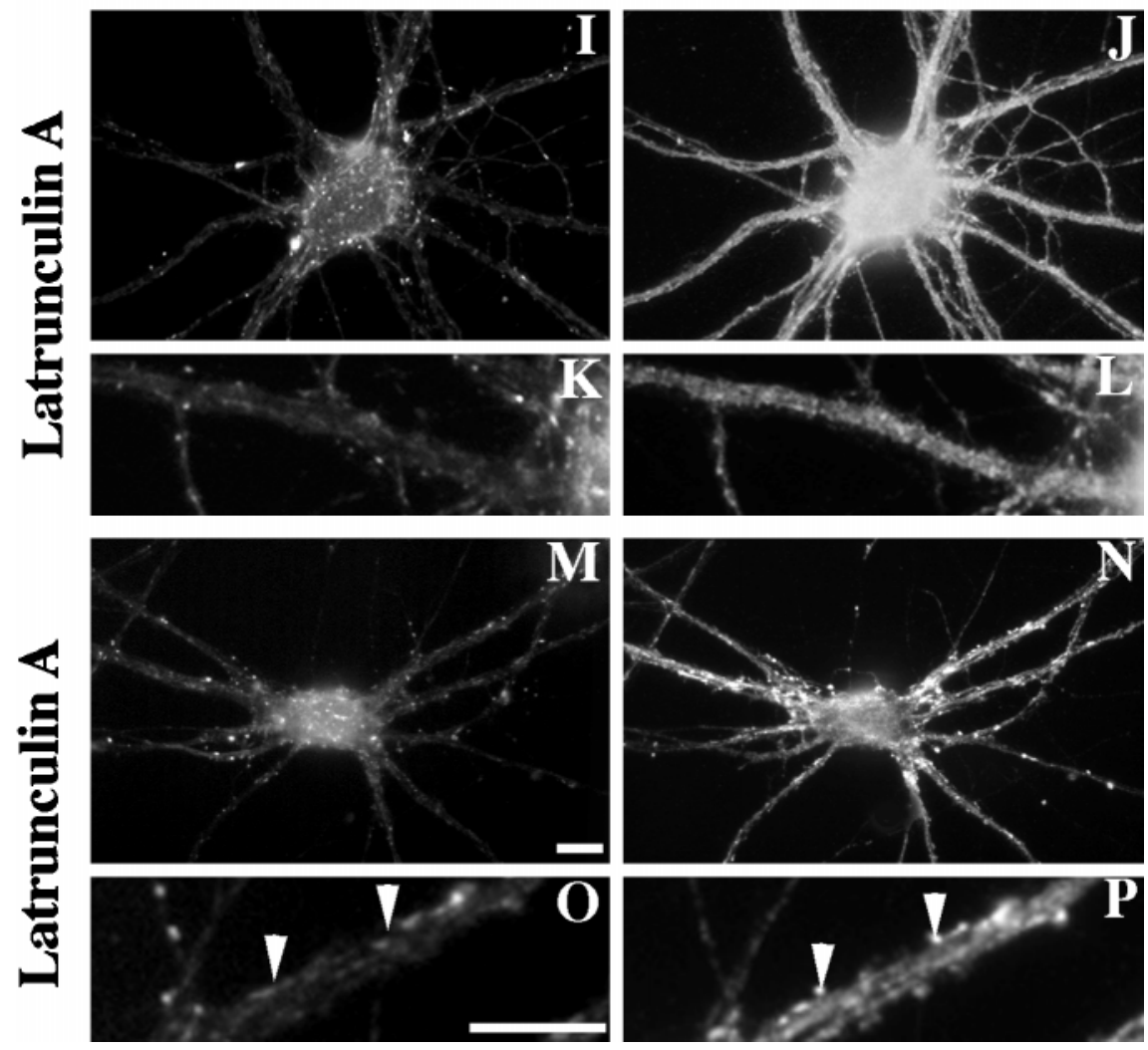

lated from the Red Sea sponge Negombata, binds to monomeric actin with a 1:1 stoichiometry, thus sequestering G-actin and resulting in net actin filament depolymerization. This compound has proven to be effective on many cell types including mouse neuroblastoma N1E-115 cells (Spector et al., 1989). Treatment of hippocampal cultures with 1.3-5 $\mu \mathrm{M}$ latrunculin A for up to $48 \mathrm{hr}$ gave very different results from the cytochalasin $\mathrm{D}$ treatment. Treatment with $5 \mu \mathrm{M}$ latrunculin A for $24 \mathrm{hr}$ (Fig. $2 I, K, M, O$ ) 

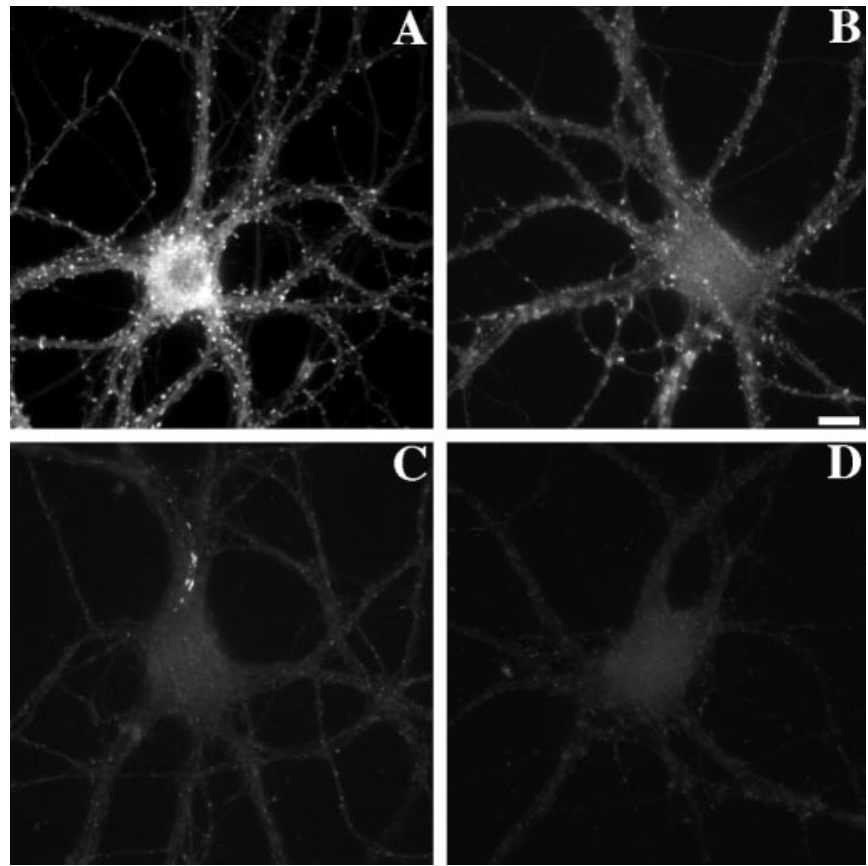

Figure 3. Time course of the effects of latrunculin A in disrupting actin polymers. Hippocampal neurons were treated at 3 weeks in culture with $5 \mu \mathrm{M}$ latrunculin A, fixed at time $0(A)$ or after $2 \mathrm{hr}(B), 9 \mathrm{hr}(C)$, or 24 hr $(D)$ of treatment, and stained for F-actin with rhodamine phalloidin. After $2 \mathrm{hr}$ of latrunculin A treatment, cortical F-actin was reduced but still detectable and in particular was concentrated in dendritic spines. After 9 $\mathrm{hr}$ of latrunculin A treatment, most of the F-actin was depolymerized, although there were still some dendrite shaft regions $(C)$ and a few spines containing F-actin (data not shown). After latrunculin A treatment for 24 $\mathrm{hr}$, the neurons were almost devoid of F-actin staining, and F-actinlabeled spines were not observed. The images in $A-D$ were taken at the same exposure and scaled equally to preserve the differences in F-actin staining. Scale bar, $10 \mu \mathrm{m}$.

resulted in a loss of F-actin from both the shafts of the neurites and the dendritic spines. In most cases, the F-actin staining was completely undetectable in the neurons; occasionally, a few small patches remained in the shafts of the neurites but not in the spines.

After $2 \mathrm{hr}$ of latrunculin A treatment, the neurons resembled the $24 \mathrm{hr}$ cytochalasin D treatment; F-actin was somewhat reduced in these neurons but still fairly abundant, particularly in dendritic spines (Fig. 3B). By 9 hr, some neurons exhibited no F-actin staining, whereas other neurons still exhibited considerable F-actin in shafts and in spines (Fig. 3C). By $24 \mathrm{hr}$ of latrunculin A treatment, there was no detectable rhodamine phalloidin staining in most neurons (Fig. 3D), except for the occasional staining of some short, extremely stable filaments within cell bodies or dendrite shafts. Treatment with latrunculin A for 48 hr was toxic; $24 \mathrm{hr}$ was therefore chosen for the following studies.

The effects of a $24 \mathrm{hr}$ latrunculin A treatment were reversible and thus did not cause any irreparable damage to the cell. Figure $4 A-D$ shows neurons treated for $24 \mathrm{hr}$ with latrunculin $\mathrm{A}$ and then allowed to recover for another $24 \mathrm{hr}$ in latrunculin A-free media. This was sufficient time for the F-actin to repolymerize within these cells, as seen with rhodamine phalloidin, and sufficient time for many of the spines to reform. This observation may indicate either that latrunculin A simply removes actin from the spines, deflating them, or possibly that the mechanism for forming new spines can occur within the $24 \mathrm{hr}$ time period. Latrun-
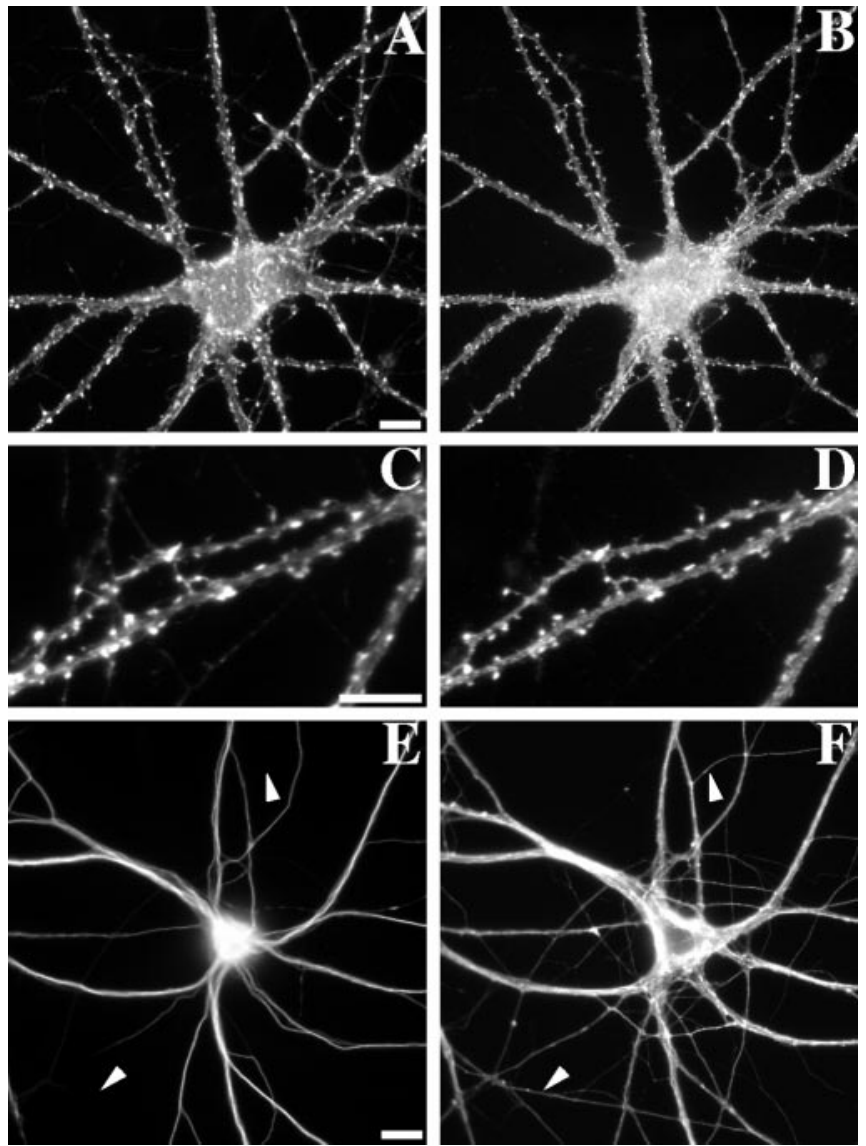

Figure 4. Reversal of latrunculin A effects and maintenance of neuronal polarity. Hippocampal neurons were treated for $24 \mathrm{hr}$ with latrunculin A $(E, F)$ and in some cases were allowed to recover for an additional $24 \mathrm{hr}$ in latrunculin A-free media $(A-D ; C$ and $D$ show enlarged regions of $A$ and $B$ ). A $24 \mathrm{hr}$ reversal lead to a complete recovery of the normal F-actin staining pattern and GluR1 clustering on dendritic spines (F-actin, $A, C$; GluR1, $B, D)$. As a control for the specificity of latrunculin $\mathrm{A}$, the distributions of the microtubule-associated proteins MAP2 (a dendritic marker, $E$ ) and tau (an axonal marker, $F$ ) were shown to be unaffected by the $24 \mathrm{hr}$ latrunculin A treatment. There was no difference in the staining patterns between latrunculin A-treated $(E, F)$ and paired control (data not shown) neurons. Arrowheads indicate axons that are tau-positive and MAP2-negative. Scale bars, $10 \mu \mathrm{m}$.

culin A treatment had no effect on neuronal polarity or on the distribution of presynaptic terminals. The microtubule-associated proteins MAP2 (a dendritic marker; Caceres et al., 1984) and tau (an axonal marker; Mandell and Banker, 1996) exhibited their normal polarized distributions after $24 \mathrm{hr}$ of latrunculin A treatment (Fig. $4 E, F)$. The synaptic vesicle protein synaptophysin also exhibited its usual punctate staining pattern indicating clustering in presynaptic terminals (see Fig. 7). Given evidence that F-actin may be important in organizing synaptic vesicles within terminals (Hirokawa et al., 1989), there may be ultrastructural differences within the terminals, but we observed no effects on synaptophysin or SV2 localization at the light microscopic level.

\section{Depolymerization of F-actin reduces the number of GluR1-labeled spines in pyramidal neurons}

AMPA receptors on pyramidal neurons seemed to depend on F-actin both for synaptic localization and for the maintenance of clusters (Figs. 2, 5). These observations are based on qualitative and quantitative immunofluorescence analyses of control versus 

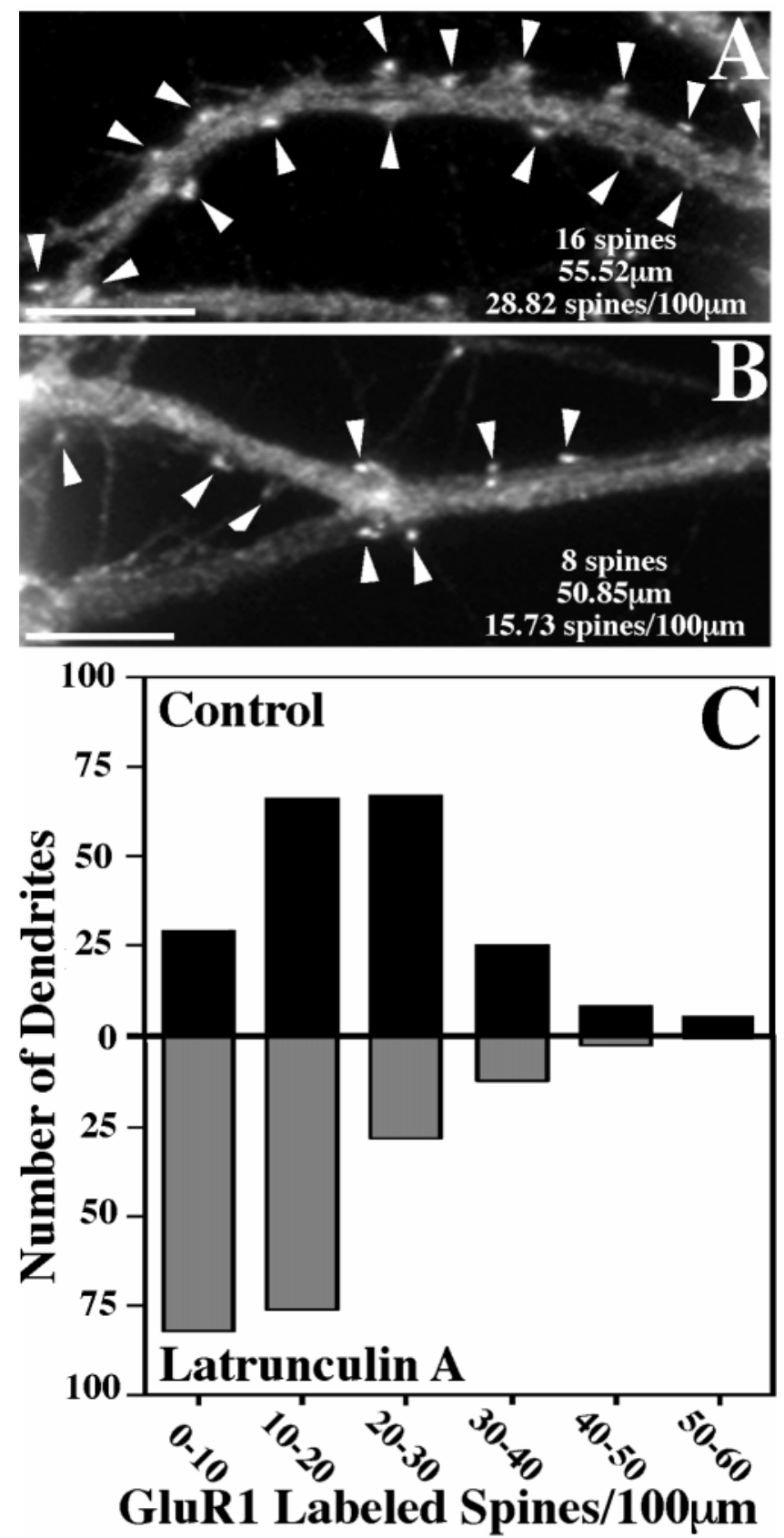

Figure 5. GluR1-labeled spines decrease in number after latrunculin A treatment. The number of GluR1-labeled dendritic spines per $100 \mu \mathrm{m}$ of dendrite length was counted for 200 control and 200 latrunculin A-treated dendrites. $A, B$, Typical counts for regions of control and latrunculin A-treated dendrites, respectively. Arrowheads represent clusters of GluR1 on dendritic spines. Many of the spines remaining after latrunculin A treatment resemble the smaller deflated spines that are typical of this treatment. $C$, These data were then compiled into a graph in histogram form, with the black bars representing control neurons and the gray bars the latrunculin A-treated neurons. Control neurons exhibited $21.68 \pm$ 0.81 (mean \pm SEM) spines per $100 \mu \mathrm{m}$, whereas latrunculin A-treated neurons had only $13.57 \pm 0.64$ (mean \pm SEM) spines per $100 \mu \mathrm{m}$. This represents a significant decrease in spine number ( $t$ test, $p<0.0001)$. Scale bars, $10 \mu \mathrm{m}$.

latrunculin A-treated 3-week cultured neurons stained with antibodies against GluR1 and synaptophysin along with rhodamine phalloidin for F-actin visualization. Randomly selected, multiply innervated cells were analyzed to determine the number of
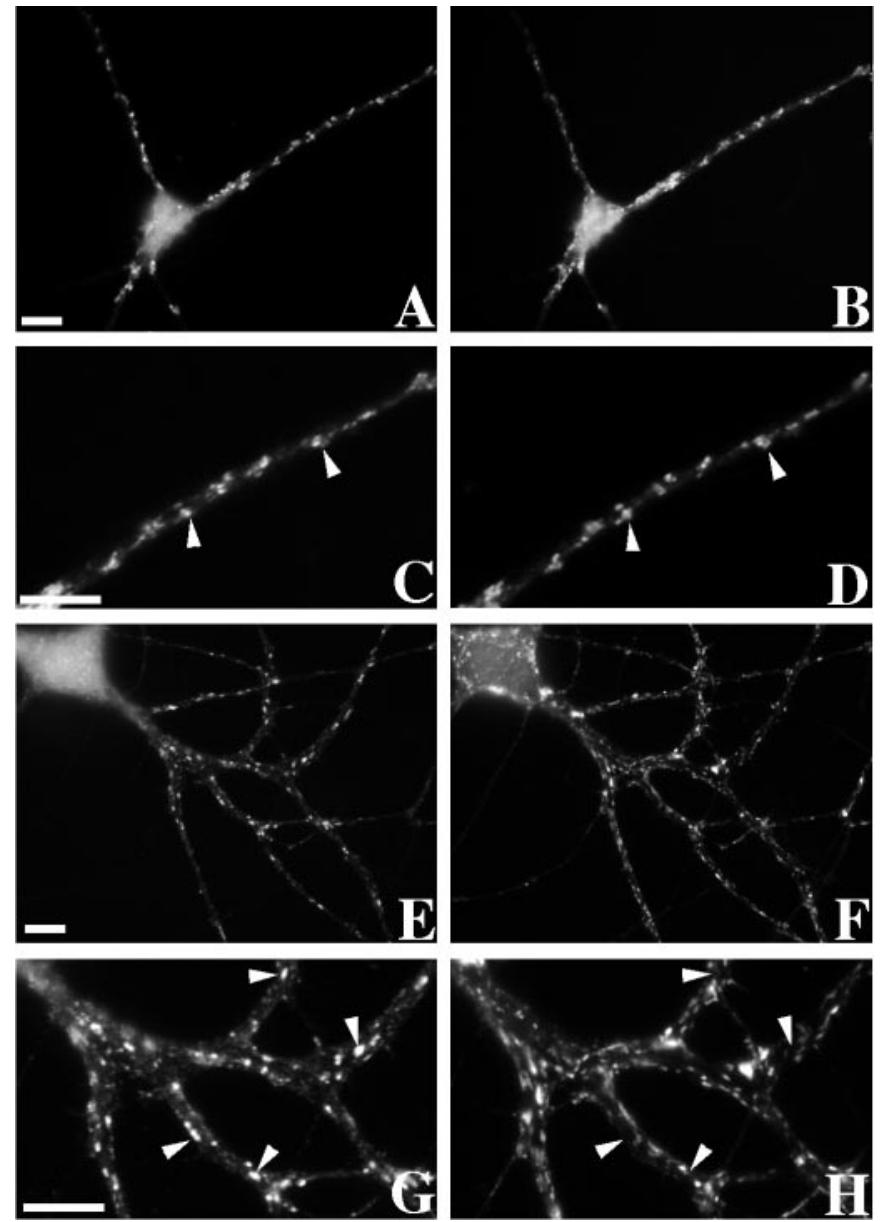

Figure 6. GABAergic neurons exhibit nonsynaptic GluR1 clusters after actin depolymerization. $A-D$, A typical GABAergic neuron immunostained for GluR1 ( $A$, enlarged region in $C$ ) and the synaptic vesicle protein SV2 $(B$, enlarged region in $D)$ is shown. GluR1 formed clusters on the dendrite shafts opposite SV2-labeled terminals in control neurons (arrowheads in $C, D$ ). $E-H$, After latrunculin A treatment to depolymerize F-actin, GluR1 still formed clusters on GABAergic neurons $(E, G)$. However, the GluR1 clusters were no longer localized to synaptic sites defined by SV2-labeled terminals $(F, H)$ but appeared to be randomly distributed in dendrites at nonsynaptic sites (arrowheads in $G, H$ ). Scale bars, $10 \mu \mathrm{m}$.

GluR1-labeled spines per dendrite length (Fig. 5A,B). Control neurons averaged from five separate cultures had $21.7 \pm 0.8$ (mean \pm SEM) GluR1-labeled spines per $100 \mu \mathrm{m}$ of dendrite length, consistent with previous results showing that GluR1 labels only a subpopulation of spines (Rao and Craig, 1997). This value decreased significantly to $13.6 \pm 0.6$ (mean \pm SEM) GluR1labeled spines per $100 \mu \mathrm{m}$ of dendrite length after latrunculin A treatment of the neurons ( $t$ test, $p<0.0001$; see Fig. 5 for complete set of data). No single latrunculin A-treated neuron exhibited what would be classified as typical spines. Many latrunculin A-treated cells exhibited no GluR1-labeled spines (Fig. $2 I-L)$. However, other neurons still exhibited what we have termed deflated spines after latrunculin A treatment (Fig. 2M-P). All of the spines, including these deflated spines, remained opposed to presynaptic terminals. Thus the lack of a normal spine structure did not necessarily cause the entire synapse to break down; $\sim 40 \%$ of the synapses lost AMPA receptor clusters, but the rest retained AMPA receptor clusters on these deflated spines. 
We did not observe any nonsynaptic clusters of GluR1 resulting from latrunculin A treatment of pyramidal neurons. Although there is significant staining for GluR1 along dendrite shafts and so shaft clusters may have been more difficult to observe, the data are most consistent with the idea that the AMPA receptors dispersed from many of the spiny clusters after actin depolymerization. After removal of latrunculin A, apparently normal GluR1-labeled spines recovered within $24 \mathrm{hr}$ (Fig. 4B,D). This recovery may involve reclustering of existing receptors or insertion of new receptors but was fairly rapid compared with the protracted time course of initial development of these GluR1labeled spines (Craig et al., 1993).

\section{Depolymerization of F-actin perturbs the synaptic localization of GluR1 clusters on GABAergic neurons}

In contrast to the results on pyramidal neurons, AMPA receptors on GABA cells seemed to depend on F-actin for synaptic localization but not for the maintenance of clusters (Fig. 6). Figure $6 A-D$ demonstrates the staining for GluR1 on a typical GABAergic cell (Craig et al., 1993), with intensely labeled receptor clusters at synapses on the dendrite shafts and low levels of nonsynaptic receptor. To determine whether these shaft GluR1 clusters were dispersed by actin disruption, we randomly selected GABAergic neurons by phase contrast in latrunculin A-treated and matched control cultures and classified them for the presence or absence of GluR1 clusters. Actin depolymerization did not disperse GluR1 from clusters on GABA cells. In the control neurons, $57.2 \%(n=145)$ of the GABAergic cells had easily identifiable GluR1 clusters; with latrunculin A treatment, $61.5 \%$ $(n=143)$ of the GABAergic cells had GluR1 clusters. However, although GluR1 clusters still remained after actin depolymerization, these clusters were usually no longer synaptic (Fig. 6E-H). Thus unlike the results on pyramidal neurons, although F-actin is not necessary for the maintenance of an AMPA receptor cluster on the GABA cells, it is necessary for proper synaptic localization.

\section{Loss of F-actin affects the synaptic distribution of the NMDA receptor}

NMDA receptor clusters were partially dependent on F-actin for synaptic localization but not for cluster maintenance (Figs. 7, 8). In cultured hippocampal neurons under conditions of spontaneous activity, the NMDA receptor is partially nonsynaptic; to induce a more spiny synaptic localization, we used chronic treatment with NMDA receptor antagonists (Rao and Craig, 1997). The pattern of localization of the essential NR1 subunit compared with synaptophysin reveals mainly synaptic shaft and spiny NR1 clusters (Fig. 7 $A, B$ ). Neurons were treated, as before, with
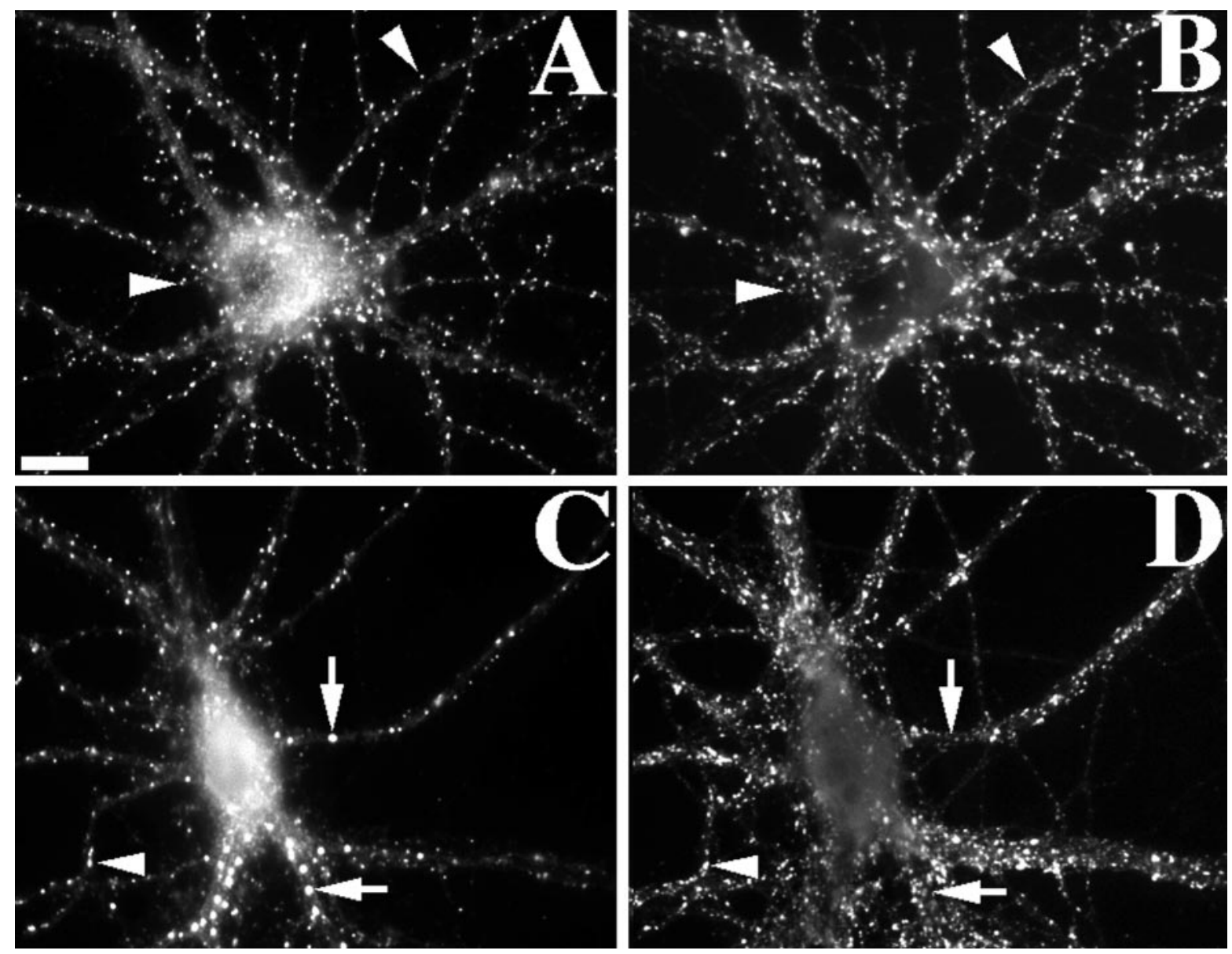

Figure 7. NR1 clusters depend partially on F-actin for their synaptic localization. Control neurons $(A, B)$ or latrunculin A-treated neurons $(C, D)$ were immunolabeled for the essential NMDA receptor subunit NR1 $(A, C)$ and for the synaptic marker synaptophysin $(B, D)$. In control neurons, NR1 formed primarily synaptic clusters (94\% synaptic) on both dendrite shafts and on spines (arrowheads). After treatment with latrunculin A, synaptic NR1 clusters were still present but reduced in number. There was also an apparent increase in the number of large nonsynaptic clusters located in dendrite shafts and cell bodies (arrows). All of these neurons were pretreated with APV from 14-21 d in culture to induce the synaptic NR1 pattern (see Rao and Craig, 1997). Scale bar, $10 \mu \mathrm{m}$. 

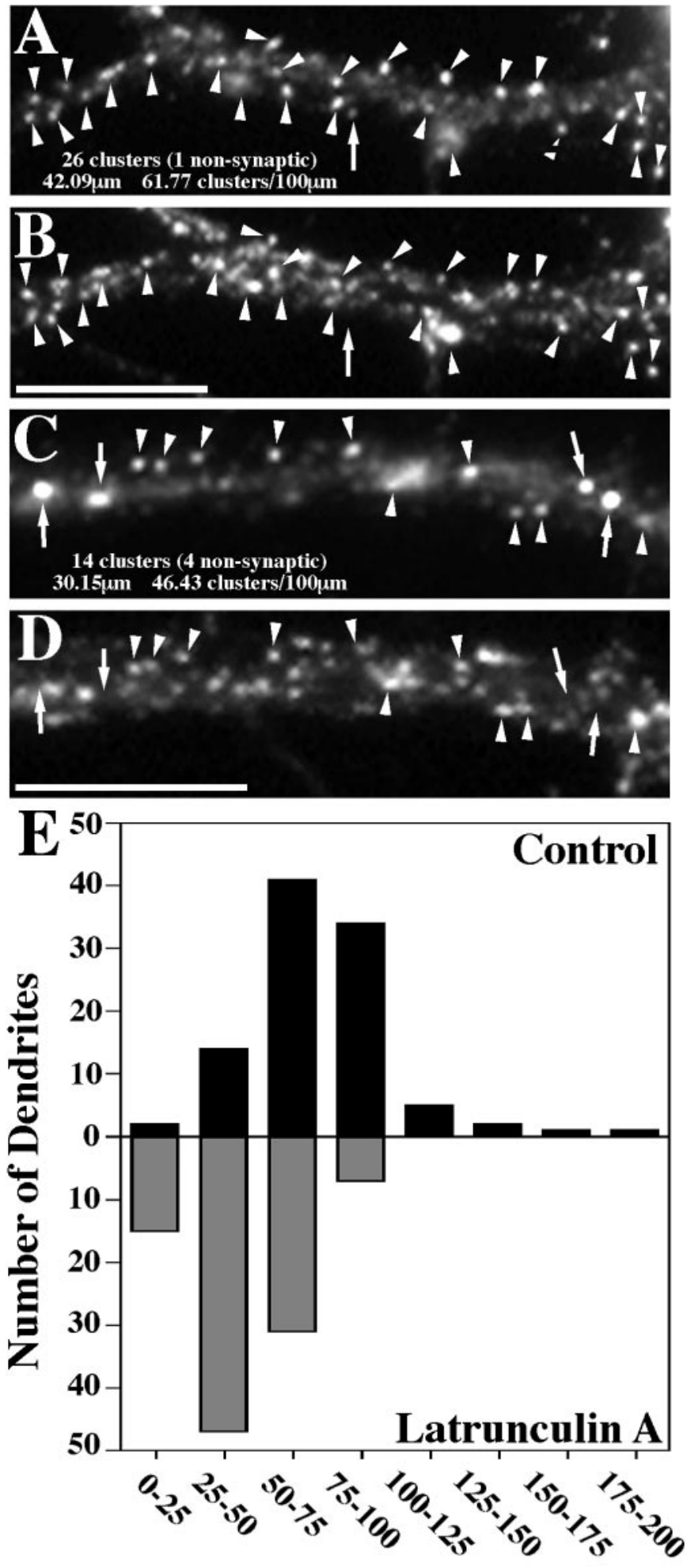

NR1 Clusters/100 $\mu \mathrm{m}$

Figure 8. NR1 clusters decrease in number after latrunculin A treatment. The number of NR1 clusters per $100 \mu \mathrm{m}$ of dendrite length was obtained by quantifying data from 100 control and 100 latrunculin A-treated dendrites. $A, B$, Regions of a control dendrite stained for NR1 and synaptophysin, respectively. $C, D$, Regions of a latrunculin A-treated dendrite stained for NR1 and synaptophysin, respectively. Arrowheads represent clusters of receptor on both spines and the shaft of the dendrites that colocalize with synaptophysin and are therefore synaptic. Arrows
$5 \mu \mathrm{M}$ latrunculin A for $24 \mathrm{hr}$ to test the effect of actin depolymerization on NMDA receptor distribution (Fig. $7 C, D$ ). The total number of NR1 clusters per $100 \mu \mathrm{m}$ of dendrite length decreased from $73.8 \pm 2.7$ for the control neurons to $44.6 \pm 1.8$ (mean \pm $\mathrm{SEM}$ ) for the latrunculin A-treated neurons ( $t$ test, $p<0.0001$; see Fig. 8 for complete set of data). This decrease in cluster number involved a selective decrease in the number of synaptic NR1 clusters from 68 to 39 clusters per $100 \mu \mathrm{m}$ of dendrite length, with no change in the number of nonsynaptic NR1 clusters. In addition, in the latrunculin A-treated cells, numerous very large nonsynaptic clusters were present in cell bodies and sometimes proximal dendrites (Fig. $7 C, D$ ) so that, overall, it appeared that the raw number of receptors changed very little (this apparent increase in nonsynaptic receptor is not represented in the numbers above, because it occurred mainly in cell bodies, and only dendritic clusters were counted). These results suggest that latrunculin A treatment induces a partial release of NMDA receptor clusters from the cytoskeleton at the synapse, dissociating the NMDA receptor cluster from its localization within the spines and resulting in movement of the clusters away from synapses. Unlike AMPA receptors, the NMDA receptors did not disperse but remained clustered or reformed clusters at the nonsynaptic sites.

\section{Actin depolymerization differentially affects the NMDA receptor interacting proteins $\alpha$-actinin-2 and PSD-95}

We next examined the distributions of two of the NMDA receptor binding proteins, $\alpha$-actinin- 2 and PSD-95, that may form a link between the receptor and the cytoskeleton. In hippocampal cultures, $\alpha$-actinin- 2 and PSD-95 are both concentrated with NMDA receptors at many excitatory postsynaptic sites (Fig. 9) (Wyszynski et al., 1997). After treatment with latrunculin A, $\alpha$-actinin-2 was completely dispersed from its typical localization at spiny synapses (Fig. 9E,G). The complete dispersal of $\alpha$-actinin-2 paralleled the near complete loss of actin filaments, despite the continued presence of some synaptic NMDA receptor clusters with latrunculin A treatment. In contrast, PSD-95 was less drastically affected by actin depolymerization. PSD-95 still clustered and colocalized with NMDA receptor clusters (Fig. 9M,O), but as was seen for NR1, the PSD-95 clusters appeared to be reduced in number and shifted toward a more nonsynaptic distribution.

\section{The localization of the inhibitory $\mathrm{GABA}_{\mathrm{A}}$ receptor is} not dependent on F-actin

$\mathrm{GABA}_{\mathrm{A}}$ receptors, visualized with an antibody against the $\beta 2 / 3$ subunits, cluster on dendrite shafts specifically opposite GABAergic terminals in hippocampal cultures (Craig et al., 1994). GABAergic synapses lack immunoreactivity for PSD-95 and $\alpha$-actinin- 2 but instead contain concentrations of gephyrin, the putative glycine receptor-anchoring protein (Craig et al.,

show NR1 clusters that do not exhibit synaptophysin staining and are thus classified as nonsynaptic. $E$, The data were then compiled into a graph in histogram form, with the black bars representing control neurons and the gray bars the latrunculin A-treated neurons. Control neurons exhibited $73.82 \pm 2.72$ (mean \pm SEM) spines per $100 \mu \mathrm{m}$, whereas latrunculin A-treated neurons had only $44.60 \pm 1.78$ (mean \pm SEM) spines per 100 $\mu \mathrm{m}$. This represents a significant decrease in total cluster number ( $t$ test, $p<0.0001)$. The number of nonsynaptic clusters on the dendrites did not change after latrunculin A treatment $(5.86 \pm 0.38$ to $5.96 \pm 0.45)$, and so the total change represents a selective decrease in synaptic NR1 clusters. The number of nonsynaptic clusters also appeared to increase in the cell bodies, which were not included in the quantitation. Scale bars, $10 \mu \mathrm{m}$. 
1996; Rao et al., 1998). Here we tested the dependence of synaptic $\mathrm{GABA}_{\mathrm{A}}$ receptor clusters on F-actin by comparing the distribution of the receptor in control versus latrunculin A-treated hippocampal cultures (Fig. 10). In control neurons, the $\mathrm{GABA}_{\mathrm{A}}$ receptor was present in a typical pattern of thin elongated clusters that colocalize with synaptophysin. Qualitatively there were no apparent differences between control and latrunculin A-treated neurons for $\mathrm{GABA}_{\mathrm{A}}$ receptor staining (compare Fig. $10 A-D$ with $E-H$ ). Most neurons had prominent synaptic clusters of the $\mathrm{GABA}_{\mathrm{A}}$ receptor with the typical elongated morphology, regardless of the degree of actin polymerization.

\section{NMDA receptors are detergent insoluble whereas AMPA receptors are readily extractable from pyramidal neurons}

As reported above, F-actin depolymerization affects both AMPA and NMDA receptors in different ways and depending on the cell type. To assess the cytoskeletal attachment of receptors, we treated living neurons with the nonionic detergent Triton X-100 to extract the plasma membrane and freely floating receptors, leaving cytoskeletal-bound receptors and the PSD associated with the detergent-insoluble fraction (Cotman et al., 1974; Cohen et al., 1977; Kennedy, 1997). Similar studies have been done to demonstrate cytoskeletal attachment of acetylcholine receptors at spontaneous clusters in cultured muscle cells by resistance to Triton X-100 extraction (Prives et al., 1982).

We used Western blot analysis to determine the relative amounts of nonextractable actin and receptors from control versus latrunculin A-treated hippocampal cultures (Fig. 11). As ex- pected without extraction, the level of actin remained relatively constant in the control and latrunculin A-treated groups (Fig. $11 E$ ). In control cultures, $\sim 50 \%$ of the actin was detergent extractable, consistent with reports that the monomeric actin pool makes up $\sim 50 \%$ of the total actin in most cells (Bray and Thomas, 1976). After actin depolymerization with latrunculin A, almost all of the actin became extractable with Triton X-100 (Fig. $11 E$, lane 4$)$. This result confirms the action of latrunculin $\mathrm{A}$ in shifting the pool of filamentous, nonextractable actin to the pool of monomeric, detergent-extractable actin in the neurons. The levels of the actin binding protein $\alpha$-actinin- 2 varied in parallel with that of actin (Fig. $11 F$ ), supporting the conclusion from the immunofluorescence staining that the cytoskeletal association of $\alpha$-actinin-2 is completely dependent on F-actin.

We next examined the effects of Triton X-100 extraction on the receptors GluR1 and NR1. Approximately $75 \%$ of the GluR1 was detergent extractable in the control cells; this proportion was not affected by the disruption of F-actin (Fig. 11G). Staining of these extracted neurons indicated that GluR1 immunoreactivity was greatly reduced on the pyramidal neurons (Fig. 11B). Although there was still some faint staining in the cell body, the typical synaptic clusters on spines were extracted. However, the staining for the GluR1 receptor on the GABAergic neurons appeared unchanged after Triton X-100 extraction (Fig. 11C). This implies that there is more than one mechanism responsible for the localization of AMPA receptors, one resistant to Triton X-100 on GABA cells and another mechanism disrupted by Triton X-100 on pyramidal neurons.

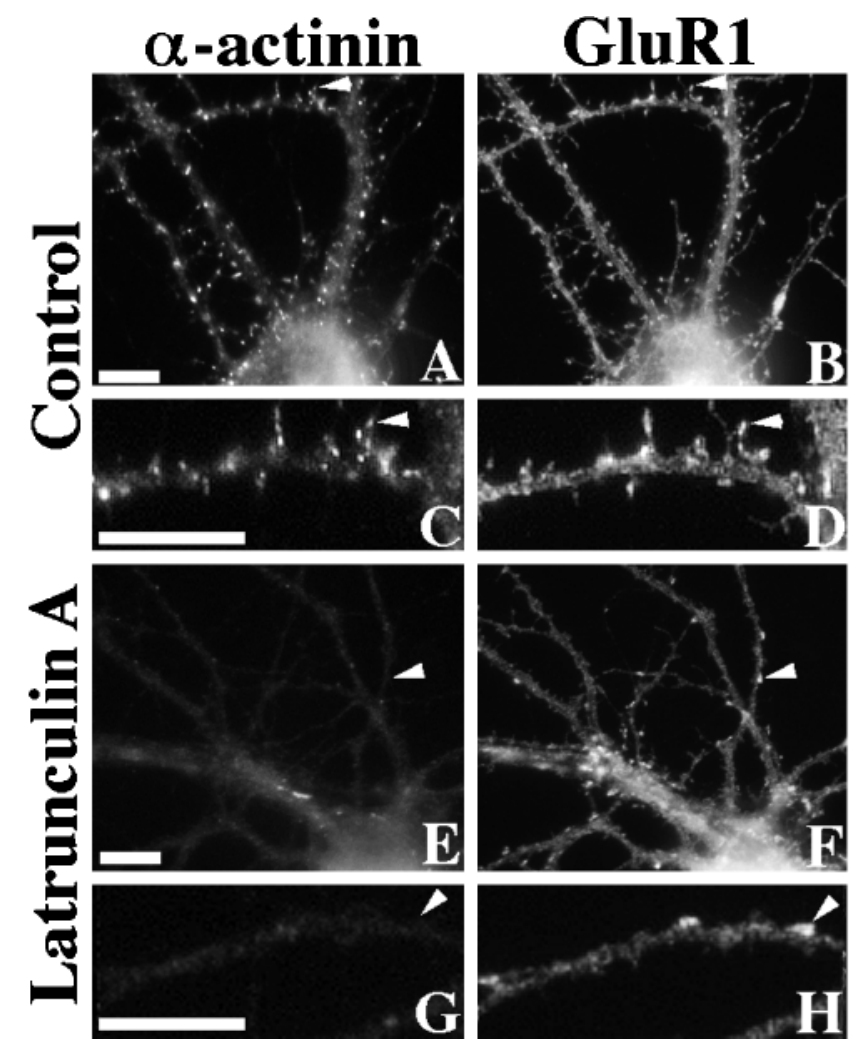

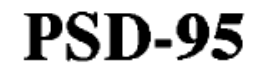
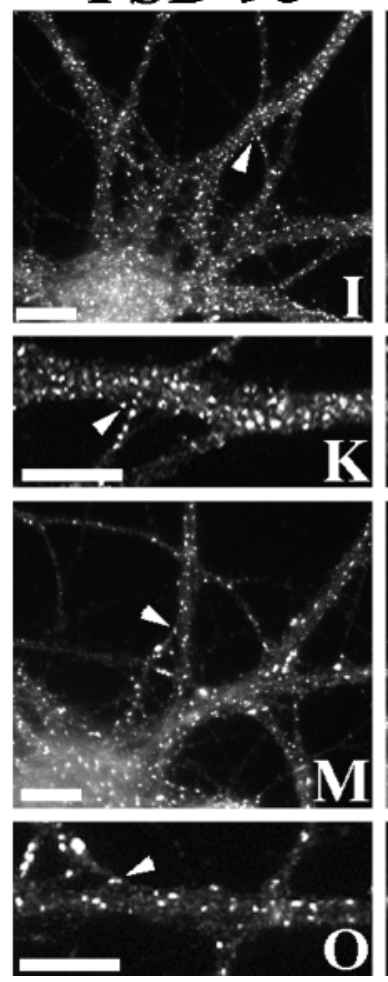

NR1
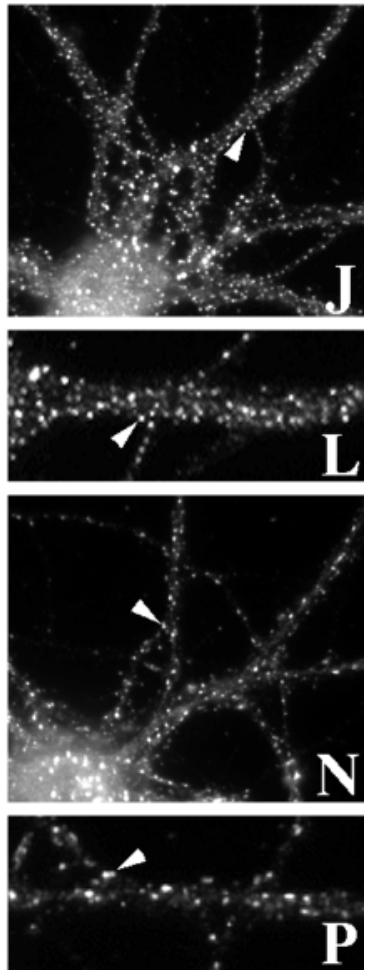

Figure 9. Differential effect of actin depolymerization on the NMDA receptor-interacting proteins $\alpha$-actinin-2 and PSD-95. Control $(A-D)$ or latrunculin A-treated $(E-H)$ neurons were immunolabeled for both $\alpha$-actinin-2 $(A, C, E, G)$ and GluR1 $(B, D, F, H)$. $\alpha$-Actinin-2 was often concentrated in dendritic spines of control neurons, partially colocalizing with GluR1 (arrowheads in $A-D$ ) (Rao et al., 1998). After latrunculin A treatment, $\alpha$-actinin-2 immunoreactivity was no longer clustered or associated with any remaining GluR1 clusters (arrowheads in $E-H)$. In contrast, PSD-95 (I, $K$, $M, O)$ colocalized closely with NR1 $(J, L, N, P)$ in both control $(I-L)$ and latrunculin A-treated $(M-P)$ neurons (arrowheads). Scale bars, $10 \mu \mathrm{m}$. 
In contrast to GluR1, NR1 was virtually unextractable, even with the disruption of F-actin (Fig. $11 H$ ). An extracted neuron stained for NR1 is shown in Figure $11 D$, with its typical synaptic clusters still present. The large spherical nonsynaptic NR1 clusters also appeared resistant to Triton X-100 extraction. The postsynaptic density is a highly insoluble structure, and these results indicate that the integrity of at least some components of this structure is not dependent on F-actin. The NR1 binding protein $\alpha$-actinin- 2 was extracted after latrunculin treatment, whereas PSD-95, like NR1, was primarily not extractable in the presence or absence of F-actin (data not shown).

\section{DISCUSSION}

From this study, several conclusions can be drawn about the relationship between postsynaptic proteins and their link to the neuronal cytoskeleton. (1) F-actin within dendritic spines is less dynamic than is the rest of the cellular actin. (2) AMPA receptors are readily detergent extractable from spines. After actin depolymerization, GluR1-labeled spines are reduced in number, and the remaining GluR1 clusters appear on collapsed spine-like structures lacking F-actin but still localizing to synaptic sites. (3) Synaptic AMPA receptors are anchored differently on GABA cell dendrite shafts, being resistant to detergent extraction and dependent on F-actin for their synaptic localization but not for the existence of clusters. (4) NMDA receptor clusters are also resistant to detergent extraction and partially depend on F-actin for their synaptic localization but not for the maintenance of clusters. (5) The NMDA receptor-interacting proteins PSD-95 and $\alpha$-actinin-2 behave differently after actin depolymerization. PSD-95 redistributes with the NMDA receptor, whereas $\alpha$-actinin-2 completely disperses despite the continued presence of some synaptic NMDA receptor clusters. (6) The localization of inhibitory $\mathrm{GABA}_{\mathrm{A}}$ receptors appears unchanged by actin depolymerization. These findings are summarized in Figure $12 A$.

\section{Stability of F-actin within dendritic spines}

F-actin within the dendritic spines exhibited a markedly increased stability compared with the rest of the neuronal cellular actin network, as revealed by treatment with either cytochalasin D (24 hr) or latrunculin A (2-9 hr). There are several actin binding proteins present within dendritic spines, including $\alpha$-actinin-2, fodrin, and MAP2 (all of which can cross-link actin filaments) and also $\alpha$-adducin, drebrin, and myosin (Caceres et al., 1983; Carlin et al., 1983; Morales and Fifkova, 1989; Seidel et al., 1995; Hayashi et al., 1996; Wyszynski et al., 1997). All of these proteins and probably more may be involved in the maintenance of the actin cytoskeleton within the dendritic spine. The effect of actin depolymerization on spine structure, shown here by the apparent loss of both GluR1- and NR1-labeled spines (Figs. 2, 5, 7, 8) and the presence of GluR1-labeled protrusions that appear to be collapsed spine-like structures, supports a central role for F-actin in maintaining spine shape. The selective stability of F-actin in spines also suggests that the regulation of spine shape is functionally important to the neuron and that this regulation is accomplished independently of the regulation of F-actin in the bulk of the neuron. Given the specificity and reversibility of its effects (Fig. 4), latrunculin A may prove to be a useful and powerful tool in further studying dendritic spine function.

\section{Relationship between F-actin and AMPA glutamate receptors}

The Triton X-100 extraction of AMPA receptors from pyramidal cell spines reported here indicates that AMPA receptors are not core components of the PSD but are less tightly linked to cytoskeletal structures at postsynaptic sites. The PSD consists of synaptosomal components that are insoluble in Triton X-100, with a core that is also insoluble in sarcosinate (Cotman et al., 1974; Cohen et al., 1977; Kennedy, 1997). Biochemical preparations indicate that the PSD is enriched in actin, fodrin, dystrophin, $\alpha$-actinin-2, PSD-95/SAP90, GKAP/SAPAP, densin 180, $\mathrm{CaM}$ kinase II, NMDA receptors, and $\mathrm{GABA}_{\mathrm{A}}$ receptors (for review, see Kennedy, 1997; also Matus et al., 1981; Kim et al., 1992, 1997; Takeuchi et al., 1997; Wyszynski et al., 1997). Mirroring our results found in culture, whereas NMDA receptors and PSD-95 family members are not extracted by Triton from rat brain synaptosomes (Muller et al., 1996), AMPA receptors are efficiently (75-85\%) extracted by Triton from adult rat hippocampal tissue homogenates (Wenthold et al., 1996).

If GluR1 is not tightly anchored to the cytoskeleton at spines, then how can it become clustered there, which it apparently does both in vivo and in cultured neurons (Petralia and Wenthold, 1992; Craig et al., 1993)? The results with latrunculin A indicate that both the existence of GluR1 clusters and their synaptic localization are partially dependent on F-actin. One possibility is that there is a direct protein-mediated link between AMPA receptors and the actin cytoskeleton but that the interactions are disrupted by Triton X-100. Alternatively, AMPA receptors may not be anchored per se but rather localized by selective membrane addition and/or membrane corrals. The cytoskeletal struc-
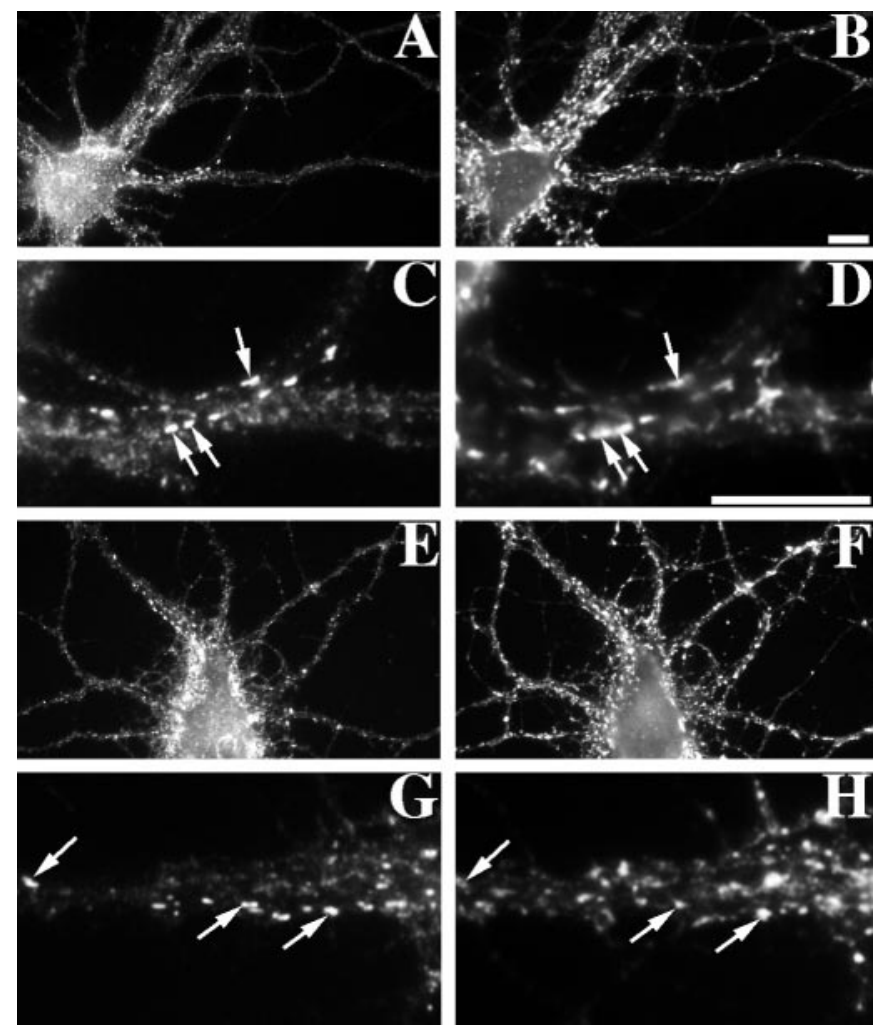

Figure 10. $\mathrm{GABA}_{\mathrm{A}}$ receptors do not depend on F-actin for clustering or synaptic localization. Control neurons $(A-D)$ or latrunculin A-treated neurons $(E-H)$ were immunolabeled for the $\mathrm{GABA}_{\mathrm{A}}$ receptor $\beta 2 / 3$ subunits $(A, C, E, G)$ and the synaptic marker $\operatorname{SV} 2(B, D, F, H)$. The $\mathrm{GABA}_{\mathrm{A}}$ receptor distribution appeared to be unaffected by actin depolymerization. Typical elongated $\mathrm{GABA}_{\mathrm{A}}$ receptor clusters were present on shafts of both control and latrunculin A-treated neurons, and these were opposite synaptic terminals (arrows). Scale bars, $10 \mu \mathrm{m}$. 
ture of PSDs at spines consists of a lattice of 3-5 nm filaments that could provide such a fence or corral (Blomberg et al., 1977; Matus and Taff-Jones, 1978; Landis et al., 1987), similar to the proposed spectrin-based corrals of erythrocytes (Bennett and Gilligan, 1993). In support of these ideas, GluR1 clusters on spines are not as "tightly clustered," i.e., the clusters never appear as brightly labeled above the diffuse labeling on the dendrite shafts as do NR1 clusters on spines or GluR1 clusters on the shafts of the GABA cells, at least in primary cultured neurons. If this model is correct, one of the functions of spines may be to sequester AMPA receptors. Future tests of this model, such as direct measurements of the mobility of receptors within the membrane (e.g., Sheetz et al., 1980), will be required.

In contrast to AMPA receptors on pyramidal cells, AMPA receptors on GABAergic neurons behaved more as expected for proteins anchored to the subsynaptic cytoskeleton. GluR1 on GABAergic neurons was not extractable by Triton X-100 and was not dependent on F-actin for the maintenance of clusters but was dependent on F-actin for the synaptic localization of those clusters. These results are consistent with a model whereby AMPA receptors bind to an interacting protein such as GRIP (Dong et al., 1997) that clusters and attaches them, directly or indirectly, to F-actin.

\section{Relationship between F-actin and NMDA receptors}

NMDA receptors on pyramidal neurons behaved as expected for proteins anchored to the subsynaptic cytoskeleton by a linker protein or series of linker proteins. NMDA receptors remained clustered after actin depolymerization, implying the presence of a cross-linking protein. However, in the absence of F-actin, many of the NR1 clusters appeared to be released from postsynaptic sites and coalesced into large nonsynaptic cell body clusters, similar to those seen during early development of these cultures (Rao et al., 1998). Latrunculin A induced a $40 \%$ loss of synaptic NMDA receptor clusters, the same percentage loss found for GluR1-labeled spines [ although there are differences in the numbers of NMDA vs AMPA receptor clusters in these cultures (Figs. 5 vs 8; discussed by Rao and Craig, 1997)]. The nonsynaptic clusters as well as the synaptic NR1 clusters were resistant to Triton X-100 extraction, indicating some form of anchoring to the cytoskeleton.

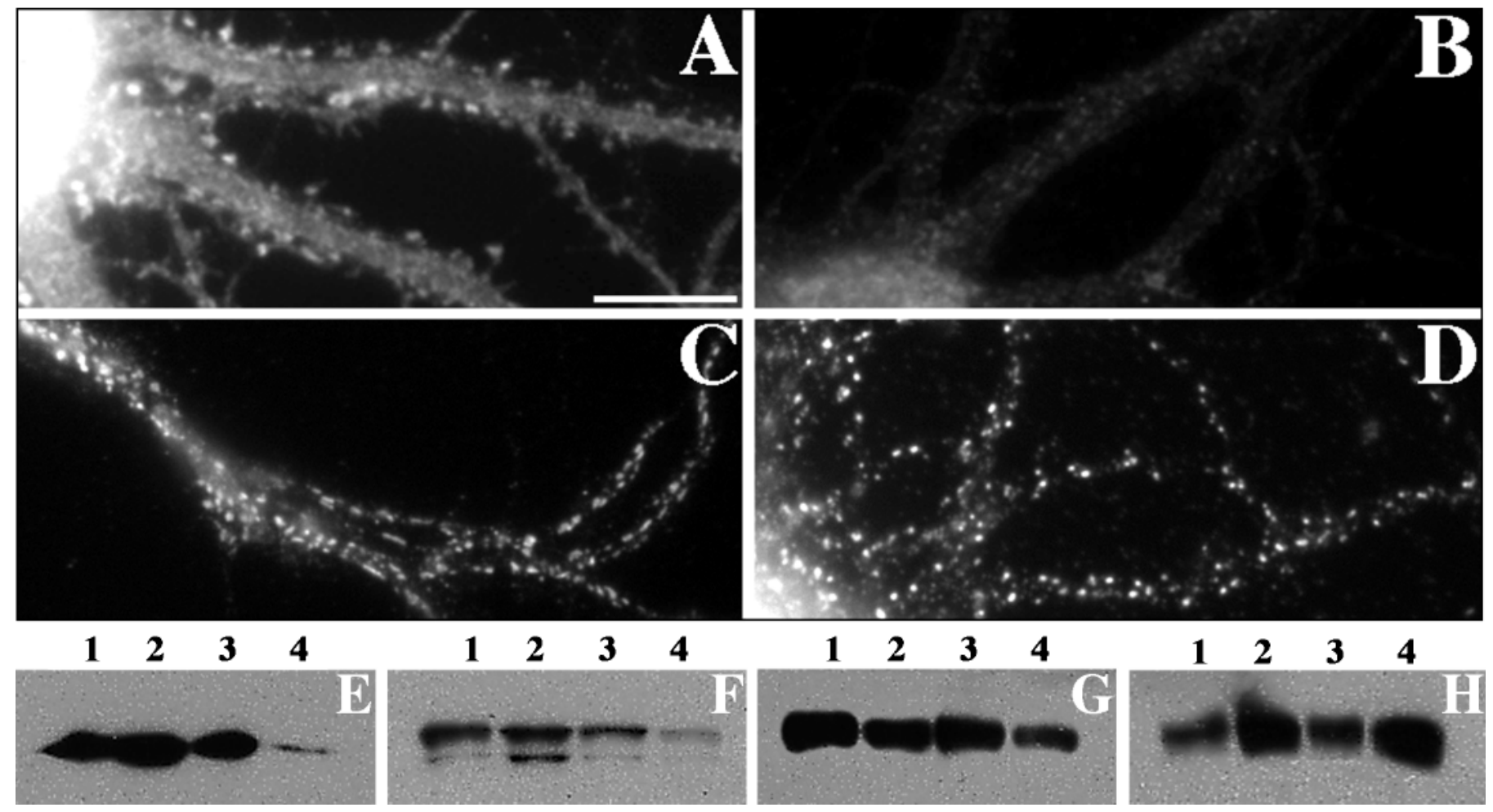

Figure 11. Detergent extraction to assess cytoskeletal anchoring of glutamate receptors. $A, B$, GluR1 staining of pyramidal neurons from the same culture taken at the same exposure either unextracted $(A)$ or after extraction with Triton X-100 $(B)$ is shown. Detergent extraction induced an obvious decrease in the amount of GluR1 immunoreactivity and a change in the distribution pattern including a complete loss of GluR1 immunoreactivity from dendritic spines. $C$, In contrast, detergent-extracted GABAergic neurons retained GluR1 clusters with a typical distribution pattern; these clusters were presumably at synaptic sites, although we were unable to confirm this directly because the synaptic markers SV2 and synaptophysin were extracted by Triton X-100 (data not shown). $D$, After Triton X-100 extraction, NR1 immunoreactivity on pyramidal neurons was also indistinguishable from that of unextracted neurons. Scale bar: $A-D, 10 \mu \mathrm{m}$. $E-H$, Western blot analyses of unextracted control neurons (lane 1$)$, control neurons extracted with $1 \%$ Triton X-100 (lane 2), latrunculin A-treated unextracted neurons (lane 3), and latrunculin A-treated, Triton X-100-extracted neurons (lane 4 ) are shown. Protein loading was normalized to cell number such that lanes 2 and 4 contain protein derived from twice as many neurons as lanes 1 and 3 . These blots were probed with antibodies against actin $(E), \alpha$-actinin-2 $(F)$, GluR1 $(G)$, and NR1 $(H)$. Very little actin remained in the latrunculin A-treated, extracted neurons $(E$, lane 4$)$, indicating that most of the F-actin was depolymerized by latrunculin A and therefore extractable. $\alpha$-Actinin-2 was also nearly completely extractable after latrunculin A treatment $(F)$; although it can also bind NMDA receptors, it apparently is highly dependent on F-actin for cytoskeletal attachment. Surprisingly, GluR1 was partially $(\sim 75 \%)$ extractable with or without F-actin present (evident by the decreased signal in lanes 2 and 4 of $G$ relative to lanes 1 and 3, despite the twofold greater loading of lanes 2 and 4 ). This result is consistent with the loss of GluR1 immunoreactivity from pyramidal neurons after extraction $(B)$. NR1 $(H)$, on the other hand, did not seem to be detergent extractable even with latrunculin A treatment (because the relative signal intensities correspond to the loading differences). 

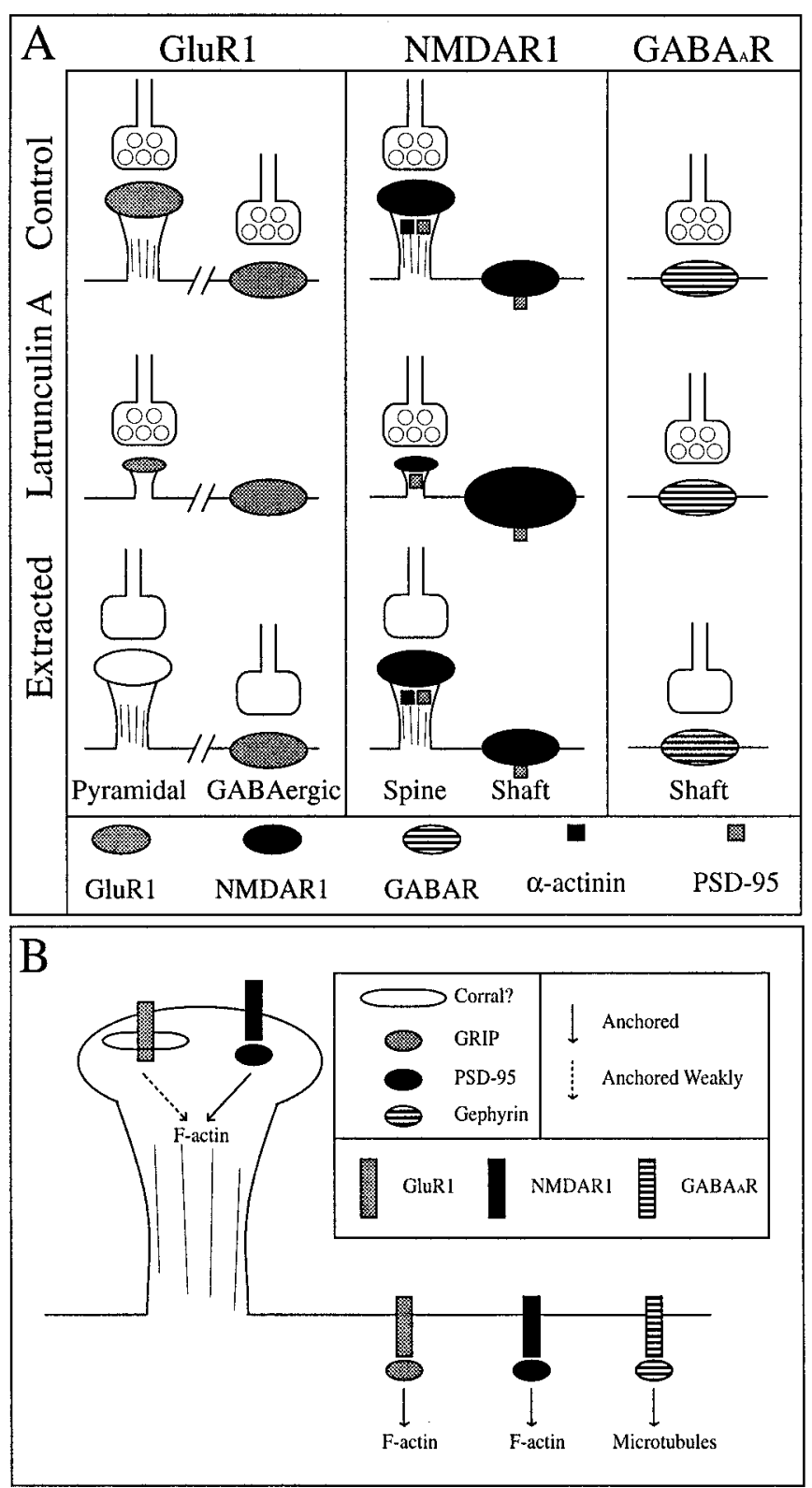

Figure 12. Diagrammatic summary of results $(A)$ and model $(B)$. $A$, In control neurons, GluR1 exhibits a cell type-specific synaptic distribution, spiny on pyramidal neurons and clustering on the shafts of GABAergic neurons. NMDAR1 shows both spiny and shaft clusters on the pyramidal neurons; in this case, some of the shaft clusters are nonsynaptic (represented by the lack of a presynaptic terminal). The spiny NR1 clusters are immunopositive for both PSD-95 and $\alpha$-actinin-2, but the shaft NR1 clusters contain only PSD-95. GABA $\mathrm{A}_{\mathrm{A}}$ receptors are found as synaptic shaft clusters on pyramidal neurons. After latrunculin A treatment to depolymerize actin, GluR1-labeled spines are decreased in number with the remaining spines being much smaller and devoid of F-actin. GluR1 shaft clusters on GABAergic neurons are no longer synaptic. Synaptic NR1 clusters are also decreased in number after actin depolymerization, and there appear to be more and/or larger nonsynaptic NR1 clusters. $\alpha$-Actinin- 2 becomes completely diffuse with the loss of F-actin, but PSD-95 remains coclustered with both synaptic and nonsynaptic NMDA receptors. The inhibitory $\mathrm{GABA}_{\mathrm{A}}$ receptor $\left(\mathrm{GABA}_{\mathrm{A}} \mathrm{R}\right)$ is apparently unaffected by latrunculin A treatment. Detergent extraction leads to a complete loss of GluR1 on the spines of pyramidal neurons but has no affect on GluR1 clusters on the shafts of GABAergic neurons. Both NR1 (and its interacting proteins $\alpha$-actinin-2 and PSD-95) and GABA recep- $_{\mathrm{A}}$ tors are not readily detergent extractable but remain tightly anchored at presumptive synaptic sites (synaptophysin is readily extractable, but the
Both synaptic and nonsynaptic NMDA receptor clusters, in the presence or absence of F-actin, were associated with PSD-95. PSD-95 by virtue of its multiple PDZ domains and ability to multimerize by N-terminal disulfide linkages (Hsueh et al., 1997) may thus be a core scaffolding molecule for the attachment of NMDA receptors at both synaptic and nonsynaptic sites. The redistribution of NR1 and PSD-95 with latrunculin A treatment observed here suggests that PSD-95 and associated NMDA receptors are linked, directly or indirectly, to the actin-based cytoskeleton. However, some synaptic PSD-95 and NMDA receptor clusters did remain in the absence of detectable F-actin. It may be that a highly cross-linked aggregate containing NMDA receptors, PSD-95 family members, associated proteins such as GKAP/ SAPAP, nNOS, and neuroligin (Brenman et al., 1996; Irie et al., 1997; Kim et al., 1997; Takeuchi et al., 1997), and possibly other PSD proteins is sufficient to maintain a partial complement of postsynaptic components in the absence of F-actin. Using latrunculin A, we have been able to dissociate $\alpha$-actinin-2 from NMDA receptor clusters, indicating that $\alpha$-actinin-2 is not necessary for clustering or for synaptic localization of NMDA receptors in pyramidal neurons. It seems likely that $\alpha$-actinin-2, competitively with calmodulin (Ehlers et al., 1996; Wyszynski et al., 1997), plays more of a modulatory role in regulating NMDA receptor function and perhaps localization in spines.

\section{General mechanisms for anchoring postsynaptic receptors}

A parallel can be drawn between this study and earlier studies of postsynaptic structure at the vertebrate neuromuscular junction. In this system, the acetylcholine receptor is anchored in the postsynaptic muscle membrane by attachment to the actin-based cytoskeleton. Extraction with Triton X-100 leaves spontaneous acetylcholine receptor clusters bound to the cytoskeleton (Prives et al., 1982), and treatment with cytochalasin D causes the receptor to disperse in small microclusters throughout the membrane (Connolly, 1984). The molecules linking the receptor to F-actin are thought to include $43 \mathrm{~K} / \mathrm{rapsyn}$ with possibly some contribution from utrophin, dystrophin, and/or dystrobrevin (Carbonetto and Lindenbaum, 1995; Sanes, 1997).

The main conclusion of this study is that a single model cannot account for the diversity of results regarding receptor anchoring at postsynaptic sites on neurons (Fig. 12). For example, our results indicate different mechanisms underlying the localization of a single receptor (the AMPA receptor) in pyramidal cells versus GABAergic interneurons and different mechanisms underlying the localization of different receptors (AMPA- vs NMDA-type glutamate receptors) at a single class of postsynaptic sites on pyramidal cell dendritic spines. These differences in mechanisms

\section{$\leftarrow$}

receptor staining patterns remain unchanged). $B$, The above data lead to a model for distinct mechanisms for anchoring of neurotransmitter receptors to the cytoskeleton, not only between different receptor types at a single site but also for the same receptor within different cell types. Particularly for GluR1 clusters on spines, the mechanism is not well understood. Many possibilities exist: a weak, detergent-extractable interaction, a spectrin-based corral, preferential membrane addition, or some other mechanism. The same receptor is anchored in a different manner in GABAergic neurons, possibly by the PDZ protein GRIP. The NMDA receptor forms clusters on spines and dendritic shafts in the presence of PSD-95 whether $\alpha$-actinin-2 is present or not, suggesting a more central role for PSD-95 in anchoring NMDA receptors and a possible modulatory role for $\alpha$-actinin-2. The $\mathrm{GABA}_{\mathrm{A}} \mathrm{R}$, which colocalizes with gephyrin, may be anchored to the microtubule cytoskeleton through gephyrin. 
may reflect different sets of anchoring proteins linking the different receptor types to the cytoskeleton, consistent with the proposed roles for gephyrin (for $\mathrm{GABA}_{\mathrm{A}}$ receptors), the PSD-95 family (for NMDA receptors), and GRIP (for some AMPA receptors). Many of the glutamate receptors may bind more than one protein for anchoring to different components of the cytoskeleton and/or may use more than one mode of localization. AMPA receptor clusters on GABA cell dendrite shafts depended on F-actin for their synaptic anchoring but not for the presence of clusters, implying the existence of a linker protein such as GRIP (Dong et al., 1997). Surprisingly, AMPA receptor clusters on dendritic spines were not tightly anchored and thus may not require such a linker protein but may be localized by other mechanisms such as selective membrane insertion and/or membrane corrals. Future studies of the dynamics of AMPA and NMDA receptor membrane insertion and mobility will be required to test these proposed mechanisms.

\section{REFERENCES}

Aoki C, Venkatesan C, Go CG, Mong JA, Dawson TM (1994) Cellular and subcellular localization of NMDA-R1 subunit immunoreactivity in the visual cortex of adult and neonatal rats. J Neurosci 14:5202-5222.

Banker GA, Cowan WM (1977) Rat hippocampal neurons in dispersed cell culture. Brain Res 126:397-425.

Bartlett WP, Banker GA (1984) An electron microscopic study of the development of axons and dendrites by hippocampal neurons in culture. II. Synaptic relationships. J Neurosci 4:1954-1965.

Baude A, Nusser Z, Roberts JD, Mulvihill E, McIlhinney RA, Somogyi P (1993) The metabotropic glutamate receptor (mGluR1 alpha) is concentrated at perisynaptic membrane of neuronal subpopulations as detected by immunogold reaction. Neuron 11:771-787.

Beck KA, Nelson WJ (1996) The spectrin-based membrane skeleton as a membrane protein-sorting machine. Am J Physiol 270:C1263-C1270.

Bennett V, Gilligan DM (1993) The spectrin-based membrane skeleton and micron-scale organization of the plasma membrane. Annu Rev Cell Biol 9:27-66.

Benson DL, Watkins FH, Steward O, Banker G (1994) Characterization of GABAergic neurons in hippocampal cell cultures. J Neurocytol 23:279-295.

Blomberg F, Cohen RS, Siekevitz P (1977) The structure of postsynaptic densities isolated from dog cerebral cortex. II. Characterization and arrangement of some of the major proteins within the structure. J Cell Biol 74:204-225.

Brakeman PR, Lanahan AA, O'Brien R, Roche K, Barnes CA, Huganir RL, Worley PF (1997) Homer: a protein that selectively binds metabotropic glutamate receptors. Nature 386:284-288.

Bray D, Thomas C (1976) Unpolymerized actin in fibroblasts and brain. J Mol Biol 105:527-544.

Brenman JE, Chao DS, Gee SH, McGee AW, Craven SE, Santillano DR, Wu Z, Huang F, Xia H, Peters MF, Froehner SC, Bredt DS (1996) Interaction of nitric oxide synthase with the postsynaptic density protein PSD-95 and alpha1-syntrophin mediated by PDZ domains. Cell 84:757-767.

Caceres A, Payne MR, Binder LI, Steward O (1983) Immunocytochemical localization of actin and microtubule-associated protein MAP2 in dendritic spines. Proc Natl Acad Sci USA 80:1738-1742.

Caceres A, Banker G, Steward O, Binder L, Payne M (1984) MAP2 is localized to the dendrites of hippocampal neurons which develop in culture. Brain Res 315:314-318.

Carbonetto S, Lindenbaum M (1995) The basement membrane at the neuromuscular junction: a synaptic mediatrix. Curr Opin Neurobiol 5:596-605.

Carlin RK, Bartelt DC, Siekevitz P (1983) Identification of fodrin as a major calmodulin-binding protein in postsynaptic density preparations. J Cell Biol 96:443-448.

Cohen RS, Blomberg F, Berzins K, Siekevitz P (1977) The structure of postsynaptic densities isolated from dog cerebral cortex. I. Overall morphology and protein composition. J Cell Biol 74:181-203.

Cohen RS, Chung SK, Pfaff DW (1985) Immunocytochemical localization of actin in dendritic spines of the cerebral cortex using colloidal gold as a probe. Cell Mol Neurobiol 5:271-284.
Connolly JA (1984) Role of the cytoskeleton in the formation, stabilization, and removal of acetylcholine receptor clusters in cultured muscle cells. J Cell Biol 99:148-154.

Cooper JA (1987) Effects of cytochalasin and phalloidin on actin. J Cell Biol 105:1473-1478.

Cotman CW, Banker G, Churchill L, Taylor D (1974) Isolation of postsynaptic densities from rat brain. J Cell Biol 63:441-455.

Craig AM, Blackstone CD, Huganir RL, Banker G (1993) The distribution of glutamate receptors in cultured rat hippocampal neurons: postsynaptic clustering of AMPA-selective subunits. Neuron 10:1055-1068.

Craig AM, Blackstone CD, Huganir RL, Banker G (1994) Selective clustering of glutamate and gamma-aminobutyric acid receptors opposite terminals releasing the corresponding neurotransmitters. Proc Natl Acad Sci USA 91:12373-12377.

Craig AM, Banker G, Chang W, McGrath ME, Serpinskaya AS (1996) Clustering of gephyrin at GABAergic but not glutamatergic synapses in cultured rat hippocampal neurons. J Neurosci 16:3166-3177.

Dong H, O'Brien RJ, Fung ET, Lanahan AA, Worley PF, Huganir RL (1997) GRIP: a synaptic PDZ domain-containing protein that interacts with AMPA receptors. Nature 386:279-284.

Ehlers MD, Zhang S, Bernhadt JP, Huganir RL (1996) Inactivation of NMDA receptors by direct interaction of calmodulin with the NR1 subunit. Cell 84:745-755.

Fifkova E, Delay RJ (1982) Cytoplasmic actin in neuronal processes as a possible mediator of synaptic plasticity. J Cell Biol 95:345-350.

Fletcher TL, Cameron P, De Camilli P, Banker G (1991) The distribution of synapsin I and synaptophysin in hippocampal neurons developing in culture. J Neurosci 11:1617-1626.

Goslin K, Banker G (1991) Rat hippocampal neurons in low density culture. In: Culturing nerve cells (Banker G, Goslin K, eds), pp 251282. Cambridge, MA: MIT.

Groweiss A, Shmueli U, Kashman Y (1983) Marine toxins of latrunculia magnifica. J Org Chem 48:3512-3516.

Harris KM, Kater SB (1994) Dendritic spines: cellular specializations imparting both stability and flexibility to synaptic function. Annu Rev Neurosci 17:341-371.

Hayashi K, Ishikawa R, Ye LH, He XL, Takata K, Kohama K, Shirao T (1996) Modulatory role of drebrin on the cytoskeleton within dendritic spines in the rat cerebral cortex. J Neurosci 16:7161-7170.

Hirokawa N, Sobue K, Kanda K, Harada A, Yorifuji H (1989) The cytoskeletal architecture of the presynaptic terminal and molecular structure of synapsin 1. J Cell Biol 108:111-126.

Hsueh YP, Kim E, Sheng M (1997) Disulfide-linked head-to-head multimerization in the mechanism of ion channel clustering by PSD-95. Neuron 18:803-814.

Irie M, Hata Y, Takeuchi M, Ichtchenko K, Toyoda A, Hirao K, Takai Y, Rosahl TW, Sudhof TC (1997) Binding of neuroligins to PSD-95. Science 277:1511-1515.

Kennedy MB (1997) The postsynaptic density at glutamatergic synapses. Trends Neurosci 20:264-268.

Kim E, Cho KO, Rothschild A, Sheng M (1996) Heteromultimerization and NMDA receptor-clustering activity of chapsyn-110, a member of the PSD-95 family of proteins. Neuron 17:103-113.

Kim E, Naisbitt S, Hsueh YP, Rao A, Rothschild A, Craig AM, Sheng M (1997) GKAP, a novel synaptic protein that interacts with the guanylate kinase-like domain of the PSD-95/SAP90 family of channel clustering molecules. J Cell Biol 136:669-678.

Kim TW, Wu K, Xu JL, Black IB (1992) Detection of dystrophin in the postsynaptic density of rat brain and deficiency in a mouse model of Duchenne muscular dystrophy. Proc Natl Acad Sci USA 89:1164211644.

Kirsch J, Betz H (1993) Widespread expression of gephyrin, a putative glycine receptor-tubulin linker protein, in rat brain. Brain Res 621:301-310.

Kirsch J, Betz H (1995) The postsynaptic localization of the glycine receptor-associated protein gephyrin is regulated by the cytoskeleton. J Neurosci 15:4148-4156.

Kirsch J, Langosch D, Prior P, Littauer UZ, Schmitt B, Betz H (1991) The $93 \mathrm{kDa}$ glycine receptor-associated protein binds to tubulin. J Biol Chem 266:22242-22245.

Kornau HC, Schenker LT, Kennedy MB, Seeburg PH (1995) Domain interaction between NMDA receptor subunits and the postsynaptic density protein PSD-95. Science 269:1737-1740.

Landis DM, Weinstein LA, Reese TS (1987) Substructure in the 
postsynaptic density of Purkinje cell dendritic spines revealed by rapid freezing and etching. Synapse 1:552-558.

Mandell JW, Banker GA (1996) A spatial gradient of tau protein phosphorylation in nascent axons. J Neurosci 16:5727-5740.

Matus A, Pehling G, Wilkinson D (1981) Gamma-aminobutyric acid receptors in brain postsynaptic densities. J Neurobiol 12:67-73.

Matus A, Ackermann M, Pehling G, Byers HR, Fujiwara K (1982) High actin concentrations in brain dendritic spines and postsynaptic densities. Proc Natl Acad Sci USA 79:7590-7594.

Matus AI, Taff-Jones DH (1978) Morphology and molecular composition of isolated postsynaptic junctional structures. Proc R Soc Lond [Biol] 203:135-151.

Morales M, Fifkova E (1989) In situ localization of myosin and actin in dendritic spines with the immunogold technique. J Comp Neurol 279:666-674.

Muller BM, Kistner U, Kindler S, Chung WJ, Kuhlendahl S, Fenster SD, Lau LF, Veh RW, Huganir RL, Gundelfinger ED, Garner CC (1996) SAP102, a novel postsynaptic protein that interacts with NMDA receptor complexes in vivo. Neuron 17:255-265.

Nomura A, Shigemoto R, Nakamura Y, Okamoto N, Mizuno N, Nakanishi S (1994) Developmentally regulated postsynaptic localization of a metabotropic glutamate receptor in rat rod bipolar cells. Cell 77:361-369.

Paoletti P, Ascher P (1994) Mechanosensitivity of NMDA receptors in cultured mouse central neurons. Neuron 13:645-655.

Papa M, Bundman MC, Greenberger V, Segal M (1995) Morphological analysis of dendritic spine development in primary cultures of hippocampal neurons. J Neurosci 15:1-11.

Peters A, Palay SL, Webster H (1991) Synapses. In: The fine structure of the nervous system: neurons and their supporting cells, pp 138-211. New York: Oxford UP.

Petralia RS, Wenthold RJ (1992) Light and electron immunocytochemical localization of AMPA-selective glutamate receptors in the rat brain. J Comp Neurol 318:329-354.

Petralia RS, Yokotani N, Wenthold RJ (1994) Light and electron microscope distribution of the NMDA receptor subunit NMDAR1 in the rat nervous system using a selective anti-peptide antibody. J Neurosci 14:667-696.
Prives J, Fulton AB, Penman S, Daniels MP, Christian CN (1982) Interaction of the cytoskeletal framework with acetylcholine receptor on the surface of embryonic muscle cells in culture. J Cell Biol 92:231-236.

Rao A, Craig AM (1997) Activity regulates the synaptic localization of the NMDA receptor in hippocampal neurons. Neuron 19:801-812.

Rao A, Kim E, Sheng M, Craig AM (1998) Heterogeneity in the molecular composition of excitatory postsynaptic sites during development of hippocampal neurons in culture. J Neurosci 18:1217-1229.

Rosenmund C, Westbrook GL (1993) Calcium-induced actin depolymerization reduces NMDA channel activity. Neuron 10:805-814.

Sanes JR (1997) Genetic analysis of postsynaptic differentiation at the vertebrate neuromuscular junction. Curr Opin Neurobiol 7:93-100.

Seidel B, Zuschratter W, Wex H, Garner CC, Gundelfinger ED (1995) Spatial and sub-cellular localization of the membrane cytoskeletonassociated protein alpha-adducin in the rat brain. Brain Res 700:13-24.

Sheetz MP, Schindler M, Koppel DE (1980) Lateral mobility of integral membrane proteins is increased in spherocytic erythrocytes. Nature 285:510-511.

Somogyi P, Takagi H, Richards JG, Mohler H (1989) Subcellular localization of benzodiazepine/GABAA receptors in the cerebellum of rat, cat, and monkey using monoclonal antibodies. J Neurosci 9:2197-2209.

Spector I, Shochet NR, Blasberger D, Kashman Y (1989) Latrunculinsnovel marine macrolides that disrupt microfilament organization and affect cell growth. I. Comparison with cytochalasin D. Cell Motil Cytoskeleton 13:127-144.

Takeuchi M, Hata Y, Hirao K, Toyoda A, Irie M, Takai Y (1997) SAPAPs. A family of PSD-95/SAP90-associated proteins localized at postsynaptic density. J Biol Chem 272:11943-11951.

Wenthold RJ, Petralia RS, Blahos II J, Niedzielski AS (1996) Evidence for multiple AMPA receptor complexes in hippocampal CA1/CA2 neurons. J Neurosci 16:1982-1989.

Wyszynski M, Lin J, Rao A, Nigh E, Beggs AH, Craig AM, Sheng M (1997) Competitive binding of alpha-actinin and calmodulin to the NMDA receptor. Nature 385:439-442. 